\title{
POBOJNOST NAMJERNOG OŠTEĆENJA VJEROVNIKA STEČAJNOG DUŽNIKA
}

Doc. dr. sc. Antun Bilić*

Doc. dr. sc. Marko Bratković**
UDK: 347.739:347.447.93(497.5)

347.739:347.933(497.5)

347.739:347.427(497.5)

DOI: 10.3935/zpfz.71.34.05

Izvorni znanstveni rad

Primljeno: travanj 2021.

Iz prakse je hrvatskih sudova razvidno da je namjerno oštećenje vjerovnika stečajnog dužnika (čl. 202. Stečajnog zakona) najčešće korištena osnova pobijanja pravnih radnji stečajnog dužnika. Po toj se osnovi mogu pobijati sve pravne radnje poduzete u kritičnom razdoblju od čak deset godina prije podnošenja prijedloga za otvaranje (pred)stečajnog postupka pa sve do otvaranja stečajnog postupka. Ovlašteni pobijatelj, međutim, u parnici ima nelak zadatak dokazati ne samo da je dužnik radnju poduzeo s namjerom oštećenja vjerovnika nego i da je protivnik pobijanja za tu namjeru znao. Te se subjektivne pretpostavke u postupku utvrduju na temelju objektivnih indicija koji su u središtu analize ovog rada. Kritička ocjena domaće sudske prakse mogla bi pripomoći njezinu ujednačenju te poslužiti kao putokaz ovlaštenim pobijateljima koje je pravne radnje oportuno pobijati.

Ključne riječi: pobijanje pravnih radnji stečajnog dužnika, namjera oštećenja vjerovnika, znanje o namjeri oštećenja vjerovnika, izravno oštećenje stečajnih vjerovnika, (prijeteća) nesposobnost za plaćanje

* Dr. sc. Antun Bilić, docent Pravnog fakulteta Sveučilišta u Zagrebu, Trg Republike Hrvatske 14, 10000 Zagreb; antun.bilic@pravo.hr;

ORCID ID: orcid.org/0000-0001-5144-0821

** Dr. sc. Marko Bratković, docent Pravnog fakulteta Sveučilišta u Zagrebu, Trg Republike Hrvatske 14, 10000 Zagreb; marko.bratkovic@pravo.hr;

ORCID ID: orcid.org/0000-0003-0893-6682 


\section{UVOD}

Interni dogovori dužnika i pojedinih osoba u određenome kritičnom razdoblju ${ }^{1}$ prije pokretanja stečajnog postupka mogu, jednom kad stečajni postupak nad dužnikom bude otvoren, u nezavidan položaj dovesti stečajne vjerovnike koji u te dogovore nisu bili uključeni. ${ }^{2}$ Opravdano je stoga da se načelo pariteta (in concursu conditio omnium creditorum par est), koje traži da se u stečaju svi vjerovnici u pravilu namiruju istovremeno, skupno i razmjerno, proširi i na određeno razdoblje prije otvaranja stečajnog postupka. ${ }^{3}$ No, potrebno je istaknuti da vjerovnici stečajnog dužnika mogu biti oštećeni i tako da dužnik u određenome kritičnom razdoblju prije otvaranja stečajnog postupka za svoju činidbu iz poduzetog pravnog posla nije primio ekvivalentnu protučinidbu od protivne strane, kasnijeg protivnika pobijanja, te da je dužnikova imovina koja ulazi u stečajnu masu zbog toga manja nego što bi bila da te štetne radnje nije bilo. To je i razlog zašto se sve takve štetne pravne radnje poduzete u tom kritičnom razdoblju mogu pobijati. Naime, bude li pravna radnja pobijena, bit će bez učinka prema stečajnoj masi, a protivna će strana u pravilu biti dužna vratiti u stečajnu masu sve imovinske koristi koje je na osnovi te radnje stekla.

Pravila pobijanja pravnih radnji stečajnog dužnika predviđena našim Stečajnim zakonom ${ }^{4}$, po uzoru na njemački Insolvenzordnung ${ }^{5}$, sadrže dosta složene

$1 \quad K$ ritično razdoblje čini se odgovarajućim izrazu koji se u literaturi na engleskom jeziku naziva suspect period. Cf. UNCITRAL Legislative Guide on Insolvency Law, United Nations, 2005., t. 150.

2 Ibid., t. 148.

3 Dika, M., Pobijanje pravnih radnji u povodu stečaja, u: Dika, M. (ur.), Treća novela Stečajnog zakona, Narodne novine, 2003., str. 147.

4 Stečajni zakon, Narodne novine, br. 71/15, 104/17 (dalje u tekstu: SZ). Pobijanje pravnih radnji stečajnog dužnika na sličan je način bilo uređeno i Stečajnim zakonom iz 1996. godine (Narodne novine, br. 44/96, 161/98, 29/99, 129/00, 123/03, 197/03, 187/04, 82/06, 116/10, 25/12, 133/12, 45/13, 71/15) pa je starija sudska praksa uglavnom relevantna i za primjenu novoga zakona. Zakon o postupku izvanredne uprave u trgovačkim društvima od sistemskog značaja za Republiku Hrvatsku (Narodne novine, br. 32/17) za pobijanje pravnih radnji dužnika također upućuje na odgovarajuću primjenu SZ-a (čl. 38. st. 2.).

5 Aktualna je verzija tog zakona Insolvenzordnung vom 5. Oktober 1994 (BGBl. I S. 2866), die zuletzt durch Artikel 6 des Gesetzes vom 22. Dezember 2020 (BGBl. I S. 3328) geändert worden ist. Bogata praksa njemačkih sudova i njemačka doktrina stoga su, uz odgovarajući oprez zbog različitih naknadnih intervencija i u njemački i u hrvatski zakon, uglavnom dobar izvor za pomoć u tumačenju i hrvatskih odredaba o pobijanju pravnih radnji stečajnog dužnika. V. vrlo detaljne komentare Schmidt, K. (ur.), Insolvenzordnung. InsO mit EuInsVO, C. H. Beck, ${ }^{19} 2016$;; Kummer, J. et al., Insolvenz- 
kombinacije lakše i teže dokazivih subjektivnih i objektivnih pretpostavaka pobijanja. Njihova bi odgovarajuća primjena trebala, nakon što nad dužnikom bude otvoren stečaj, osigurati pravičnu ravnotežu između kolektivnog interesa stečajnih vjerovnika za očuvanjem stečajne mase, dužnikova interesa da slobodno raspolaže svojom imovinom i interesa trećih osoba, protivnika pobijanja, da dužnikovu imovinu stječu. ${ }^{6}$ Koliko će ta ravnoteža biti uspostavljena, ovisi ponajviše o sudovima. ${ }^{7}$

Namjera oštećenja vjerovnika kao kvalificirano subjektivno stanje dužnikove svijesti, ocjena je zakonodavca, opravdava pobojnost njegovih pravnih radnji poduzetih u razdoblju koje i nije neposredno u vezi s otvaranjem stečaja nad dužnikom. Naime, kod pobijanja je namjernog oštećenja vjerovnika u prvom planu sankcioniranje dužnikova fraudolozna postupanja. Dužnikovu namjeru, međutim, u načelu nije lako dokazati.

Činilo se zato korisnim istražiti kojim se to indicijima rukovode hrvatski sudovi u ocjeni je li došlo do namjernog oštećenja vjerovnika stečajnog dužnika. Vode li pritom primjerenu brigu o uspostavi ravnoteže suprotstavljenih interesa vjerovnika, dužnika i protivnika pobijanja? Ovaj je rad stoga utemeljen na istraživanju, usustavljivanju i kritičkoj ocjeni bogate domaće sudske prakse. Komentar u ovom radu ocrtanih indicija mogao bi poslužiti ujednačenju sudske prakse te kao putokaz ovlaštenim pobijateljima trebaju li in concreto pokretati pobijajuće ${ }^{8}$ parnice ili će ih to vjerojatno izvrgnuti nepotrebnu dodatnu utrošku vremena i novca.

anfechtung. Fallgruppenkommentar, Otto Schmidt, ${ }^{3} 2017$.; Stürner, R.; Eidenmüller, H.; Schoppmeyer, H. (ur.), Münchener Kommentar zur Insolvenzordnung, C. H. Beck, ${ }^{4} 2019$;; Hirte, H; Vallender, H. (ur.), Insolvenzordnung, Franz Vahlen, ${ }^{15} 2019$; Kübler, B. M.; Prütting, H.; Bork, R. (ur.), InsO. Kommentar zur Insolvenzordnung, RWS, ${ }^{87} 2021$.

6 Cf. Guide, op. cit. u bilj. 1, t. 154; Radović, V., Stečajno pravo. Knjiga druga, Univerzitet u Beogradu, Pravni fakultet, ${ }^{2} 2018 .$, str. 30; Eraković, A., Pobijanje dužnikovih pravnih radnji, Pravo i porezi, vol. 19, br. 1, 2010., str. 12; Bilić, A., Pretpostavke pobijanja dužnikovih pravnih radnji po Zakonu o obveznim odnosima i Stečajnom zakonu, Aktualnosti zakonodavstva i prakse, vol. 24, 2017., str. 298.

7 Slično i Skorup, V., Pobijanje pravnih radnji dužnika po Zakonu o obveznim odnosima $i$ Stečajnom zakonu, Pravo u gospodarstvu, vol. 53, br. 2, 2014., str. 355.

8 Izraz pobijajuća parnica čini se semantički primjerenijim od izraza pobojna parnica koji se katkad koristi u literaturi (npr. Dika, op. cit. u bilj. 3, str. 198; Pavlović, M., Pobijanje pravnih radnji u stečaju, Hrvatska pravna revija, vol. 3, br. 10, 2003., poglavlje 7.) i sudskoj praksi. 
Da bi pravna radnja dužnika nad kojim je otvoren stečaj bila uspješno pobijena zbog namjernog oštećenja vjerovnika, ovlašteni pobijatelj ${ }^{9}$ u parnici protiv protivnika pobijanja ${ }^{10}$ treba dokazati (l) da je nad dužnikom otvoren stečaj ${ }^{11}$; (2) da je suspektnu radnju ${ }^{12}$ poduzeo dužnik ili onaj koji ga ovlašteno zastupa ${ }^{13}$, i to (3) u kritičnom razdoblju od deset godina prije podnošenja prijedloga za otvaranje (pred)stečajnog postupka pa sve do otvaranja stečajnog postupka; (4) da je tom radnjom poremećeno pravo na ujednačeno namirenje stečajnih vjerovnika $^{14}$; (5) da je protivnik pobijanja tom radnjom stekao određenu imo-

9 Aktivno je za podnošenje pobijajuće tužbe legitimiran stečajni dužnik, u ime kojega je podnosi stečajni upravitelj, i to na temelju odobrenja suda i, ako je riječ o parnici znatne vrijednosti, suglasnosti odbora (ili skupštine) vjerovnika (čl. 212. st. 1.; čl. 230. st. 1. i st. 2. t. 3. SZ-a; tako i Garašić, J., Najznačajnije novine Stečajnog zakona iz 2015. godine, Zbornik Pravnog fakulteta Sveučilišta u Rijeci, vol. 38, br. 2, 2017., str. 162; Majstorović, D., Pobijanje pravnih radnji stě̌ajnog dužnika u novom Stečajnom zakonu, Aktualnosti hrvatskog zakonodavstva i pravne prakse, vol. 22, 2015., str. 635, navodi da nedostatak suglasnosti odbora (skupštine) vjerovnika nije procesna smetnja, ali može biti razlog za "smjenu" (zapravo razrješenje) stečajnog upravitelja. Podredno su pobijajuću tužbu ovlašteni podnijeti i stečajni vjerovnici (čl. 212. st. 4. SZ-a). Tužba mora biti podnesena u zakonom propisanom roku (čl. 212. st. 3. i st. 4. SZ-a). Pravne radnje stečajnog dužnika mogu se, međutim, pobijati i isticanjem prigovora u parnici, bez vremenskog ograničenja (čl. 212. st. 11. SZ-a).

10 U parnici pokrenutoj tužbom stečajnog upravitelja ili stečajnih vjerovnika (v. prethodnu bilješku) pasivno je legitimirana osoba prema kojoj je pobijana radnja poduzeta (čl. 212. st. 2. SZ-a) te, podredno, njezini univerzalni i, pod određenim pretpostavkama, singularni sljednici (čl. 214. SZ-a).

11 Pravne posljedice otvaranja stečajnog postupka nastupaju u trenutku kada je rješenje o otvaranju stečajnog postupka objavljeno na mrežnoj stranici e-Oglasna ploča sudova (čl. 158. st. l. SZ-a).

12 S pravnom je radnjom izjednačeno i propuštanje zbog kojega je stečajni dužnik izgubio kakvo pravo ili kojim su protiv njega imovinskopravni zahtjevi bili zasnovani, održani ili osigurani (čl. 198. st. 2. SZ-a), npr. propuštanje podizanja tužbe protiv vjerovnika, propuštanje ulaganja pravnih lijekova, propuštanje isticanje prigovora zastare u parničnom postupku. Tako Čuveljak, J., Komentar Stečajnog zakona (NN 71/15, 104/17), Narodne novine, 2018., str. 650. Propuštanje je pobojno samo ako se za njega znalo i ako ga se htjelo. Tako i Pavlović, op. cit. u bilj. 8, poglavlje 2.1.

13 Ganter/Weinland, u: Schmidt (ur.), op. cit. u bilj. 5, § 133/16; Radović, op. cit. u bilj. 6, str. 105; Dika, op. cit. u bilj. 3, str. 186.

14 U čl. 198. st. 1. SZ-a pogodovanje je pojedinih vjerovnika neopravdano izdvojeno kao zasebna kategorija pobojnih radnji iako je jasno da je i pogodovanje vjerovnika samo oblik oštećenja vjerovnika. Tako i Garašić, op. cit. u bilj. 9, str. 161. I ovdje je potrebno istaknuti da vjerovnici stečajnog dužnika mogu biti oštećeni ne samo zbog povrede načela pariteta nego i time što dužnik u određenome kritičnom razdoblju prije otvaranja stečajnog postupka za svoju činidbu iz poduzetog pravnog 
vinsku korist ${ }^{15}$; (6) da je dužnik radnju poduzeo s namjerom oštećenja svojih vjerovnika i (7) da je protivnik pobijanja u vrijeme poduzimanja radnje znao o toj dužnikovoj namjeri.

Osim, dakle, općih pretpostavaka pobijanja koje se trebaju dokazati kod svih osnova pobijanja predviđenih Stečajnim zakonom ${ }^{16}$, kod pobijanja se namjernog oštećenja vjerovnika moraju dokazati i posebne pretpostavke: da je dužnik pravnu radnju poduzeo u kritičnom razdoblju od deset godina prije podnošenja prijedloga za otvaranje (pred)stečajnog postupka pa do otvaranja stečajnog postupka upravo s namjerom oštećenja svojih vjerovnika i da je protivnik pobijanja u vrijeme poduzimanja radnje za takvu dužnikovu namjeru znao. Tim su posebnim pretpostavkama posvećena tri zasebna poglavlja ovog rada, dok su zaključne ocjene u završnom dijelu rada.

\section{KRITIČNO RAZDOBLJE OD DESET GODINA}

Zbog namjernog je oštećenja vjerovnika pobojna svaka pravna radnja stečajnog dužnika poduzeta u kritičnom razdoblju od čak deset godina prije podnošenja prijedloga za otvaranje stečajnog postupka pa sve do njegova otvaranja. ${ }^{17}$ Ako

posla nije primio ekvivalentnu protučinidbu od protivne strane, kasnijeg protivnika pobijanja, te je dužnikova imovina koja ulazi u stečajnu masu zbog toga manja nego što bi bila da te štetne radnje nije bilo.

15 Protivnik pobijanja dužan je, naime, u stečajnu masu vratiti sve imovinske koristi stečene na osnovi pobijene radnje (čl. 212. st. 7. i st. 10. SZ-a).

16 Te su opće pretpostavke izvan središta interesa u ovom radu pa su ovdje samo kratko ocrtane. V. amplius Dika, op. cit. u bilj. 3, str. 147 sqq.; Čuveljak, op. cit. u bilj. 12, str. 620 sqq.; Hrastinski Jurčec, Lj., Novine u zakonskom uređenju instituta pobijanja pravnih radnji stečajnog dužnika, Informator, vol. 63. br. 6398, 2015., str. 8; Hrastinski Jurčec, Lj., Novine u zakonskom uređenju instituta pobijanja pravnih radnji stečajnoga dužnika. 2. dio, Informator, vol. 64., br. 6399, 2016., str. 6; Pavlović, op. cit. u bilj. 8, poglavlje 3; Bork, R., Einführung in das Insolvenzrecht, Mohr Siebeck, ${ }^{6} 2012$., str. 128.

17 To znači da je nakon otvaranja stečajnog postupka moguće pobijati i neke pravne radnje za koje je rok od jedne godine za pobijanje namjernog oštećenja izvan stečaja već odavno istekao (čl. 71. st. 1. Zakona o obveznim odnosima (Narodne novine, br. 35/05, 41/08, 125/11 , 78/15, 29/18; dalje u tekstu: ZOO). Pravila pobijanja pravnih radnji vjerovnika stečajnog dužnika su uopće dosta različita u odnosu na odgovarajuća pravila pobijanja izvan stečaja, što može izazvati nemale probleme. O tome v. iscrpno Bilić, op. cit. u bilj. 6, passim, osobito 342 sqq. Njemačko i austrijsko pravo predviđaju kritično razdoblje od deset godina i za pobijanje namjernog oštećenja izvan stečaja. Kayser/Freudenberg, u: Stürner et al., op. cit. u bilj. 5, § 133/lb; Henckel, W., Anfechtung im Insolvenzrecht. Kommentar, De Gruyter Recht, 2008., § 133/2. 
je prije otvaranja stečajnog postupka već vođen predstečajni postupak, kritično se razdoblje računa od dana podnošenja prijedloga za otvaranje predstečajnog postupka (čl. 208. st. 3. SZ-a). ${ }^{18}$ Iako se, dakle, u čl. 202. st. 1. SZ-a izrijekom spominje razdoblje od deset godina prije podnošenja prijedloga za otvaranje stečajnoga postupka, u čl. 208. st. 3. SZ-a određeno je da se kritično razdoblje, ako je prije otvaranja stečajnog postupka već vođen predstečajni postupak, računa od podnošenja prijedloga za otvaranje predstečajnog postupka. ${ }^{19}$

Konkretno, ako je prijedlog za otvaranje (pred)stečajnog postupka podnesen, primjerice, 1. travnja 2021., načelno se mogu pobijati sve pravne radnje koje poduzeo dužnik od, uključivo, 1. travnja 2011. pa sve do trenutka kada rješenje o otvaranju stečajnog postupka bude objavljeno na mrežnoj stranici e-Oglasna ploča sudova (čl. 158. st. 1. SZ-a). ${ }^{20}$

Ako je podneseno više prijedloga za otvaranje stečajnog postupka, u obzir se uzima onaj prvi "dopušteni i obrazloženi”21 prijedlog, čak i ako je postupak otvoren na temelju nekoga kasnijeg prijedloga (čl. 208. st. 2. SZ-a). Neujednačena je, međutim, praksa naših sudova o tome uzima li se u obzir taj prvi prijedlog čak i ako naknadno bude povučen, a stečajni postupak obustavljen. Neki kritično razdoblje u tom slučaju računaju od podnošenja kasnijeg prijedloga ${ }^{22}$, a drugi od prvog prijedloga pod uvjetom da se stečajni dužnik čitavo vrijeme između

18 Kritično se razdoblje računa od podnošenja prijedloga za otvaranje (pred)stečajnog postupka, a ne od dana otvaranja stečajnog postupka da se ne bi dodatno umanjivala mogućnost pobijanja pravnih radnji poduzetih u kritičnom razdoblju. Slično i Hrastinski Jurčec, ... 2. dio, op. cit. u bilj. 16, str. 6.

19 Dalje u radu kritično se razdoblje uvijek naznačuje u odnosu na podnošenje prijedloga za otvaranje (pred)stečajnog postupka upućujući tako da duljina kritičnog razdoblja ovisi o tome je li u konkretnom slučaju prije otvaranja stečajnog postupka vođen predstečajni postupak.

20 Iznimno, pravne radnje poduzete nakon otvaranja stečajnog postupka koje ostaju na snazi prema pravilima o zaštiti povjerenja u javne knjige mogu se pobijati prema pravilima o pobijanju pravnih radnji poduzetih prije otvaranja stečajnog postupka (čl. 215. SZ-a).

${ }^{21}$ Izraz obrazloženi prijedlog u sudskoj se praksi tumači kao osnovani prijedlog. Tako Čuveljak, op. cit. u bilj. 12, str. 683, i Dika, op. cit. u bilj. 3, str. 160, pozivajući se na to da u odgovarajućoj njemačkoj odredbi tako i stoji (begründet).

22 Tako Vrhovni sud RH (dalje u tekstu: VSRH), Revt 34/07-2 od 28. ožujka 2007.; VSRH, Revt 9/07-2 od 11. listopada 2007.; Visoki trgovački sud RH (dalje u tekstu: VTS), P̌̌-204/04-6 od 28. prosinca 2007.; VSRH, Revt 66/07-2 od 21. svibnja 2008.; VTS, P̌̌-3192/06-3 od 23. prosinca 2008.; VSRH, Revt 94/09-2 od 16. rujna 2009.; VSRH, Revt 170/10-2 od 5. svibnja 2015.; VSRH, Revt 164/10-2 od 19. svibnja 2015.; VSRH, Revt 72/08-2 od 20. svibnja 2015. 
povlačenja prvog i podnošenja kasnijeg prijedloga nalazio u gospodarskoj krizi, odnosno da su kod njega bili ostvareni stečajni razlozi. ${ }^{23}$

Pravna se radnja smatra poduzetom u vrijeme nastupanja njezinih pravnih učinaka. Ako je pravna radnja s uvjetom ili rokom, u obzir se uzima vrijeme njezina poduzimanja, a ne vrijeme nastupanja uvjeta ili isteka roka (čl. 209. st. 1. i 4. SZ-a). Ako je za učinak nekoga pravnog posla potreban upis u kakav javni upisnik, smatrat će se da je pravni posao poduzet već onda kad su, kumulativno, bile ispunjene ostale pretpostavke za njegovu valjanost, kad izjava volje o upisu postane obvezujuća za dužnika i kad druga strana podnese zahtjev za upis pravne promjene u upisnik (čl. 209. st. 2. SZ-a). ${ }^{24}$ Pravna radnja prijenosa prava vlasništva u kontekstu pobijanja smatrat će se, dakle, poduzetom već kad prijedlog za upis ${ }^{25}$ prava vlasništva bude podnesen zemljišnoknjižnom sudu, a ne tek kada taj upis bude proveden u zemljišnim knjigama.

U svakom slučaju, valja napomenuti da se izraz pravni posao iz odredbe čl. 209. st. 2. SZ-a ne odnosi na obveznopravne poslove kojima samo nastaje obveza upisa, a valjanost kojih ne ovisi o tome jesu li oni i ispunjeni upisom u odgovarajući upisnik. Valjanost, primjerice, ugovora o kupoprodaji nekretnine ne ovisi o upisu prijenosa prava vlasništva u zemljišne knjige, stoga se pravni posao iz odredbe čl. 209. st. 2. SZ-a odnosi na davanje izjave podobne za upis u zemljišne knjige (clausula intabulandi), što je jednostrani pravni posao zaseban u odnosu na ugovor o kupoprodaji. Obveznopravni ugovor, naime, stvara obvezu i prije upisa prijenosa stvarnoga prava u zemljišne knjige. U našoj se sudskoj praksi, međutim, nerijetko nedovoljno uočava razlika između tih dviju pravnih radnji. Nije zato pravilan zaključak naših sudova da je za valjanost obveznopravnog

23 Tako VTS, P̌̌-425/03-4 od 27. travnja 2005.; VTS, Pž-8668/03-4 od 7. prosinca 2005.; VTS, P̌̌-197/04-5 od 10. svibnja 2005.; VTS, Pž-8666/03-4 od 10. kolovoza 2005.; VTS, Pž-198/04 od 4. listopada 2005.; VTS, P̌̌-3781/03-5 10. listopada 2005.; VTS, Pž-6630/03 od 8. studenog 2005.; VTS, P̌̌-194/04-3 od 12. travnja 2006.; VTS, Pž-3778/03-5 od 6. rujna 2006.; VTS, Pž-203/04-3 od 24. listopada 2006; VTS, P̌̌-3780/03-3 od 24. listopada 2006.; VTS, P̌̌-743/05-3 od 25. studenog 2008.; VTS, P̌̌-4611/06-6 od 14. travnja 2009.; pravno shvaćanje VTS-a od 21. prosinca 2009. citirano u odluci Ustavnog suda RH U-III-4963/2008 od 30. ožujka 2011.; VSRH, Revt 195/16-2 od 13. rujna 2016. V. amplius Čuveljak, op. cit. u bilj. 12, str. 684 sqq.; Dika, M., Pravne posljedice otvaranja stečajnoga postupka, Narodne novine, 2002., str. 153 sq.; Dika, op. cit. u bilj. 3, str. 161 sqq.

24 Čini se da bi upravo tako trebalo shvatiti potonju odredbu iako neodgovarajuća zakonska terminologija lako može zbuniti.

25 To se odnosi i na predbilježbu (čl. 209. st. 3. SZ-a). 
ugovora potrebno podnošenje prijedloga za upis u zemljišne knjige. ${ }^{26}$ Pravilno je, s druge strane, da učinci sporazuma o javnobilježničkom založnopravnom osiguranju nastaju tek od trenutka solemnizacije ugovora. ${ }^{27}$ Založno pravo, doduše, nastaje tek upisom u zemljišne knjige, ali sklopljeni sporazum proizvodi pravne učinke već od trenutka solemnizacije.

Valja istaknuti da namjera oštećenja vjerovnika kao i znanje protivnika pobijanja o toj njegovoj namjeri moraju postojati u vrijeme poduzimanja radnje. Ako je poduzeto više sukcesivnih pravnih radnji, što je nerijetko slučaj, važno je imati na umu koja se to točno radnja pobija. Ako se, primjerice, pobija ugovor o kupoprodaji nekretnine, treba dokazati da je dužnikove namjere oštećenja vjerovnika bilo već u trenutku sklapanja ugovora o kupoprodaji. Ako se pak pobija sam prijenos vlasništva, onda će relevantan trenutak za dokazivanje namjere biti trenutak podnošenja prijedloga za upis stjecanja prava vlasništva. Kao što je već istaknuto, obveznopravni posao kupoprodaje je pravna radnja različita od pravnog posla kojim se prenosi pravo vlasništva i kojim se ugovor o kupoprodaji zapravo ispunjava.

\section{DUŽNIKOVA NAMJERA OŠTEĆENJA VJEROVNIKA}

Namjera se uobičajeno definira kao volja i znanje proizvesti određene pravne učinke. ${ }^{28}$ Namjera oštećenja vjerovnika stoga "uključuje svijest dužnika o prijetećoj nesposobnosti za plaćanje te nemogućnosti namirenja svih vjerovnika i njegovu volju da se (...) ošteti druge vjerovnike". ${ }^{29}$

Dužnikovo znanje o oštećenju vjerovnika podrazumijeva da je on makar okvirno morao biti svjestan da će njegova radnja oštetiti vjerovnike. Drugim riječima, namjere oštećenja vjerovnika nema ako je dužnik smatrao da njegova radnja ne može oštetiti stečajne vjerovnike ili da će ti vjerovnici i usprkos poduzetoj radnji biti namireni. Kod voljnog je elementa namjere važno istaknuti da se

26 Tako, međutim, npr. VTS, Pž-198/04 od 4. listopada 2005.; VTS, P̌̌-6630/03 od 8. studenog 2005.; VTS, Pž-6671/03-4 od 25. travnja 2006.; VTS, Pž-3890/04-3 od 6. veljače 2007; VTS, Pž-5868/06-3 od 6. listopada 2009.; VTS, Pž-1136/09 od 14. travnja 2010.; VTS, Pž-9992/14-3 od 18. lipnja 2015.; VTS, Pž-7184/2016-6 od 28. lipnja 2017.

27 Tako VTS, P̌̌-2371/00-3 od 14. lipnja 2000. i VTS, Pž-1230/03 od 28. prosinca 2005.

28 Klarić, P.; Vedriš, M., Građansko pravo, Narodne novine, ${ }^{112008 ., ~ s t r . ~} 597$.

29 VSRH, Revt 379/15-2 od 21. studenoga 2017. (isticanja naša). Slično i VSRH, Revt 316/13-2 od 5. svibnja 2015. Usporedivo i VTS, P̌̌-201/03-3 od 7. studenoga 2006. 
ne traži izravna namjera, da je volja stečajnog dužnika bila primarno usmjerena na oštećenje vjerovnika. ${ }^{30}$ Dostatna je i neizravna namjera (dolus eventualis), da je stečajni dužnik znao i prihvatio oštećenje vjerovnika kao nužnu posljedicu svoje radnje. ${ }^{31}$ Namjera oštećenja, dakle, postoji “ako dužnik općenito hoće oštećenje vjerovnika kao posljedicu svoje radnje ili ako zna da bi ono moglo nastupiti pa je na [to] pristao". ${ }^{32}$ Dostatno je da je stečajni dužnik oštećenje vjerovnika mogao imati u vidu kao moguću posljedicu svoje radnje i da je na nju pristao. ${ }^{33}$

Budući da je dužnikovo unutrašnje stanje svijesti često nemoguće utvrditi, namjera se utvrđuje na temelju nekih vanjskih, objektivnih pokazatelja. Sudovi često napominju da se dužnikova namjera procjenjuje na temelju "gospodarskih kriterija". ${ }^{34}$ Zapravo je riječ o analizi indicija koji sugeriraju da namjera postoji, odnosno ne postoji. Nema univerzalne formule koja bi kvantificirala svaki od indicija i njihov međusobni odnos. Konačnu ocjenu mora donijeti sud uzimajući u obzir sve okolnosti konkretnog slučaja. U nastavku su izloženi neki od indicija koji mogu poslužiti kao smjernice za ocjenu je li dužnik suspektnu pravnu radnju poduzeo s namjerom oštećenja vjerovnika ili ne.

Inkongruentno pokriće. Inkongruentnost (nesukladnost) dužnikova pokrića ${ }^{35}$ jedan je od jačih indicija dužnikove namjere oštećenja vjerovnika. Inkongruentnost se pokrića utvrđuje uspoređivanjem onoga što je dužnik bio dužan poduzeti s onime što je uistinu poduzeo. ${ }^{36} \mathrm{O}$ inkongruentnu je pokriću riječ ako je stečajni dužnik dao protivniku pobijanja nešto što nije dugovao jer zahtjev protivnika pobijanja prema njemu nikada nije nastao, ili je već prestao

30 Drukčije bi se, međutim, moglo zaključiti iz nekih sudskih odluka u kojima se navodi da se namjera procjenjuje prema tome je li oštećenje vjerovnika bilo "motiv za poduzimanje pravne radnje” (VTS, P̌̌-6430/03-3 od 27. rujna 2006.; VTS, P̌̌6913/03-4 od 24. listopada 2006.), što ne bi trebalo prihvatiti.

31 Dika, op. cit. u bilj. 3, str. 186; Henckel, op. cit. u bilj. 17, § 133/24; Ganter/Weinland, u: Schmidt (ur.), op. cit. u bilj. 5, § 133/34; Kayser/Freudenberg, u: Stürner et al., op. cit. u bilj. 5, § 133/13a; Bork, op. cit. u bilj. 16, str. 136.

32 VSRH, Revt 208/12-2 od 4. srpnja 2012. Slično i VTS, Pž-7427/04-3 od 12. srpnja 2005.; VSRH, Revt 42/06-2 od 5. travnja 2006.; VTS, Pž-3270/03-3 od 6. lipnja 2006.; VTS, P̌̌-6159/05-3 od 21. listopada 2008.; VSRH, Revt 45/12-2 od 12. veljače 2013.; VSRH, Revt 134/12-2 od 16. studenog 2016.; VTS, P̌̌-2810/2015-2 od 26. travnja 2017.

33 Radović, op. cit. u bilj. 6, str. 105; Bork, op. cit. u bilj. 16, str. 137. Slično i VTS, P̌̌2954/05-3 od 19. kolovoza 2008.

34 VTS, P̌̌-2810/2015-2 od 26. travnja 2017. Slično i VTS, Pž-6159/05-3 od 21. listopada 2008.

35 Dika, op. cit. u bilj. 3, str. 187; Henckel, op. cit. u bilj. 17, § 133/33.

36 Ganter/Weinland, u: Schmidt (ur.), op. cit. u bilj. 5, § 131/11. 
postojati, ili ga je dužnik mogao odbiti korištenjem svojih prigovora. Isto vrijedi i ako je stečajni dužnik primio nešto što nije imao pravo zahtijevati ili barem ne $\mathrm{u}$ to vrijeme ili na taj način (ako je, primjerice, primio ustupanje umjesto ispunjenja). ${ }^{37}$ Sva inkongruentna pokrića pobuđuju sumnju da je riječ o namjernom oštećenju vjerovnika, osobito ako su dana ili primljena pod uvjetima koji su manje povoljni za stečajnog dužnika. ${ }^{38}$

Naši su sudovi tako prepoznali namjeru oštećenja vjerovnika kad je stečajni dužnik svoj dug prema protivniku pobijanja podmirio ustupom tražbine ${ }^{39}$, osobito ako je to bilo zabranjeno pozitivnim propisima ${ }^{40}$, i kad je stečajni dužnik umjesto isplate novca pristao na ustup bezvrijednih dionica. ${ }^{41}$ Namjeru oštećenja vjerovnika sudovi su iščitali i iz okolnosti da je stečajni dužnik, umjesto ranije ugovorenog sredstva osiguranja, protivniku pobijanja fiducijarno prenio vlasništvo na nekretninama. ${ }^{42}$

Neće se, međutim, raditi o namjeri oštećenja vjerovnika ako postoji opravdan razlog za davanje odnosno primanje inkongruentna pokrića. Tako je sud našao da "zaključak da pružanje inkongruentnog pokrića uvjetuje namjeru oštećenja može biti isključen ako okolnosti upućuju na to da je pobojna radnja poduzeta iz drugih, pobojno irelevantnih motiva i da je stoga svijest o oštećenju vjerovnika bila u drugom planu." ${ }^{13}$ Do toga dolazi osobito kada je davanje inkongruentna pokrića sastavni dio ozbiljna, iako u konačnici, neuspješna pokušaja sanacije. "Namjera bi oštećenja nedostajala već i tada kada bi dužnik bio svjestan da je pokušaj saniranja opterećen rizikom, ali su nastojanja da se trgovačko društva spasi bila u prvom planu." ${ }^{44} \mathrm{U}$ konkretnom slučaju sud je ocijenio da je osiguranje tražbine protivnika pobijanja fiducijarnim prijenosom vlasništva bio jedini način da stečajni dužnik proda robu i riješi se nepovoljna kredita. Iako je stečajni dužnik bio svjestan mogućnosti stečaja, smatrao je da postoji vjerojatnost da na

${ }_{37} C f$. definiciju inkongruentna pokrića iz čl. 200. st. 1. SZ-a, koje se tamo ne posve odgovarajuće naziva inkongruentnim namirenjem. Tako i Dika, op. cit. u bilj. 3, str. 180.

38 Dika, op. cit. u bilj. 3, str. 180 sqq.; Henckel, op. cit. u bilj. 17, § 131/8-74; Kayser/ Freudenberg, u: Stürner et al., op. cit. u bilj. 5, § 131/13-44a; Ganter/Weinland, u: Schmidt (ur.), op. cit. u bilj. 5, § 131/20-89.

39 VSRH, Revt 72/07-2 od 4. srpnja 2007.

40 VTS, Pž-0681/03-3 od 16. svibnja 2006.

41 VSRH, Revt 458/2017-3 od 26. veljače 2019.

42 VTS, Pž-201/03-3 od 7. studenog 2006.

43 VTS, Pž-3270/03-3 od 6. lipnja 2006.

44 Ibid. 
taj način iziđe iz blokade računa. Njegovo bi poslovanje, zaključio je sud, bilo još i ranije prekinuto da nije dao osiguranje koje je predmet pobijanja.

Kongruentno pokriće. Ako je pak stečajni dužnik dao upravo ono što je dugovao, odnosno ako je primio ono što je potraživao (kongruentno, sukladno pokriće $\left.{ }^{45}\right)$, njegova je namjera oštećenja vjerovnika u pravilu isključena. ${ }^{46} \mathrm{U}$ tom slučaju, naime, stečajni dužnik djeluje u skladu sa sadržajem svoje obveze, odnosno prava pa se i druga strana, prema kojoj je pravna radnja poduzeta, ima pravo pouzdati u konačnost te radnje. ${ }^{47}$

Ipak, ako je stečajni dužnik bio svjestan da će kongruentno pokriće onemogućiti namirenje ostalih vjerovnika, on je djelovao s neizravnom namjerom oštećenja vjerovnika. ${ }^{48}$ To će najčešće biti slučaj ako je stečajnom dužniku u trenutku poduzimanja radnje prijetila nesposobnost za plaćanje ili je već bio nesposoban za plaćanje. ${ }^{49}$

Valja ovdje napomenuti da su pravne radnje kongruentna i inkongruentna pokrića u korist kojega od stečajnih vjerovnika poduzete u kritičkom razdoblju od tri mjeseca prije podnošenja prijedloga za otvaranje (pred)stečajnog postupka pa do otvaranja stečajnog postupka pobojne, uz ispunjavanje posebnih pretpostavaka, i po zasebnim osnovama za pobijanje iz čl. 199. i čl. 200. SZ-a. U tom slučaju na ovlaštenom je pobijatelju da, ako suspektna pravna radnja udovoljava i pretpostavkama namjernog oštećenja, ocijeni po kojoj mu je osnovi pogodnije pobijati tu radnju. Pretpostavke za pobijanje po osnovi (in)kongruentna pokrića u korist kojega od stečajnog vjerovnika u pravilu je lakše dokazati negoli pretpostavke za pobijanje po osnovi namjernog oštećenja vjerovnika. ${ }^{50}$ Međutim, kod namjernog oštećenja protivnik pobijanja ne mora ujedno biti i stečajni vjerovnik.

45 Cf. definiciju kongruentna pokrića iz čl. 199. st. 1. SZ-a, koje se tamo ne posve odgovarajuće naziva kongruentnim namirenjem. Tako i Dika, op. cit. u bilj. 3, str. 174.

46 Sud je tako našao da nije postojala namjera oštećenja jer je dužnik dao zalog kao ugovoreno sredstvo osiguranja kredita (VTS, Pž-2182/02 od 14. lipnja 2005.).

47 Ede/Hirte, u: Hirte; Vallender (ur.), op. cit. u bilj. 5, § 130/5.

48 Dika, op. cit. u bilj. 3, str. 186, smatra da je potrebno da je u tom slučaju dužnik više želio oštećenje ostalih vjerovnika negoli ispunjenje svoje obveze prema jednome od njih. Slično i Bork, op. cit. u bilj. 16, str. 137.

49 Ganter/Weinland, u: Schmidt (ur.), op. cit. u bilj. 5, § 133/59. V. infra poglavlje 3. (Prijeteća) nesposobnost za plaćanje.

50 U načelu bi se, doduše, u kritičnom razdoblju od pet godina prije podnošenja prijedloga za otvaranje (pred)stečajnog postupka pa sve do otvaranja stečajnog postupka moglo pobijati i osiguranje zajma kojim se nadomješta kapital, a u kritičnom razdoblju od jedne godine i namirenje zajma kojim se nadomješta kapital (čl. 204. SZ-a) te pravne radnje kojima se tajnom članu društva njegov ulog vraća ili kojima 
Izravno oštećenje vjerovnika. Kongruentnost pokrića ne govori ništa o temeljnom pravnom poslu kojim je nastalo pravo na to pokriće. Lako je zamislivo da stečajni dužnik kongruentno ispunjava ugovor kojim je namjerno oštetio svoje vjerovnike. Međutim, u tom slučaju ne bi trebalo pobijati pravnu radnju pokrića nego osnovni pravni posao na temelju kojega je i nastalo pravo na pokriće. ${ }^{51}$ Osnovni će pravni posao po svojoj naravi uglavnom biti dvostranoobvezni ugovor. U takvu se ugovoru o namjeri oštećenja vjerovnika najčešće može zaključiti iz nejednake vrijednosti činidbe i protučinidbe ${ }^{52}$, što se procjenjuje s obzirom na njihovu tržišnu vrijednost. Takvo oštećenje stečajnih vjerovnika, za koje nije potreban daljnji razvoj događaja ${ }^{53}$, koje, dakle, samo po sebi izaziva "štetnu posljedicu za namirenje vjerovnika" ${ }^{44}$, naziva se izravno oštećenje.

"Ako je tržišna vrijednost poslovnog udjela znatno veća od ugovorene vrijednosti, vjerovnici su izravno oštećeni ugovorom" jer je prodajom poslovnih udjela po manjoj cijeni društvu nastala imovinska šteta u vidu izgubljene dobiti. ${ }^{55}$ Isto tako, ako je dužnik prodao stan po oko 70.000 kuna nižoj cijeni negoli ga je prije četiri godine kupio, njegovi su vjerovnici time izravno oštećeni, to više što su cijene nekretnina u međuvremenu još i porasle. ${ }^{56}$ Sud je zaključio da su stečajni vjerovnici izravno oštećeni i iz činjenice što je ugovorena cijena niža od tržišne, a protivnik pobijanja se umjesto isplate cijene dužniku obvezao podmiriti njegove još nedospjele dugove iz kredita koji mu je dala treća osoba. ${ }^{57}$

mu se oprašta njegov udio u nastalom gubitku (čl. 205. SZ-a). Pobijanja tih radnji u našoj sudskoj praksi gotovo da i nema, ponajprije zbog uske i složene definicije zajma kojim se nadomješta kapital u našemu Zakonu o trgovačkim društvima (Narodne novine, br. 111/93, 34/99, 121/99, 52/00, 118/03, 107/07, 146/08, 137/09, 152/11, $111 / 12,125 / 11,68 / 13,110 / 15,40 / 19)$, u kojemu se taj zajam, po uzoru na starije njemačko uređenje, odnosi samo na zajam člana društva dan društvu u vrijeme kad je ono u krizi, i to onaj koji je član društva dao društvu umjesto da mu je pribavio vlastiti kapital kada bi mu ga inače uredni gospodarstvenici trebali pribaviti (čl. 408.). Dika, op. cit. u bilj. 3, str. 192 sqq.; Bilić, op. cit. u bilj. 6, str. 325 sqq.

51 Henckel, op. cit. u bilj. 17, § 129/111; § 132/12; Ganter/Weinland, u: Schmidt (ur.), op. cit. u bilj. 5, § 132/15-16.

52 Ganter/Weinland, u: Schmidt (ur.), op. cit. u bilj. 5, § 132/24.

53 Dika, op. cit. u bilj. 3, str. 165; Henckel, op. cit. u bilj. 17, § 129/91; Schmidt, u: Schmidt (ur.), op. cit. u bilj. 5, § 129/57; Kayser/Freudenberg, u: Stürner et al., op. cit. u bilj. 5, § 129/113.

54 VTS, Pž-945/05-3 od 21. veljače 2006. Slično i VTS, Pž-2502/05-3 od 27. veljače 2008.

55 VTS, Pž-6380/03-4 od 24. listopada 2006.

56 VTS, P̌̌-6913/03-4 od 24. listopada 2006.

57 VTS, P̌̌-7739/03-3 od 13. prosinca 2006. 
I izravno oštećenje vjerovnika zasebna je zakonska osnova pobijanja pravnih radnji stečajnog dužnika (čl. 201. SZ-a), ali su pobojne samo pravne radnje poduzete u relativno kratkom kritičkom razdoblju od tri mjeseca prije podnošenja prijedloga za otvaranje (pred)stečajnog postupka pa do otvaranja stečajnog postupka. Ako je do izravna oštećenja došlo prije toga, ono svakako može poslužiti kao jedan od indicija namjernog oštećenja. ${ }^{58}$

Izravno je oštećenje vjerovnika, dakako, isključeno ako su činidba i protučinidba u trenutku ugovaranja jednake vrijednosti. ${ }^{59}$ Valja istaknuti da nije riječ o izravnu oštećenju vjerovnika ni u slučaju da dužniku nije isplaćena kupoprodajna cijena iako je ugovorena cijena bila odgovarajuća. Dužnik je, naime, u tom slučaju imao pravo zahtijevati ispunjenje obveze plaćanja cijene ili pak raskinuti ugovor i zahtijevati vraćanje onoga što je dao. ${ }^{60} \mathrm{U}$ dosta su predmeta, međutim, sudovi pogrešno zaključili da je samo zato što dužniku nije bila isplaćena kupoprodajna cijena došlo do izravna oštećenja vjerovnika. ${ }^{61} \mathrm{O}$ izravnu bi oštećenju vjerovnika u tim slučajevima mogla biti riječ tek kad ugovorena cijena ne bi bila odgovarajuća.

Izravno oštećenje naplatnim ugovorom s bliskom osobom. Ako je do izravna oštećenja stečajnih vjerovnika došlo naplatnim ugovorom sklopljenim između stečajnog dužnika i njemu bliske osobe u kritičnom razdoblju od dvije godine prije podnošenja prijedloga za otvaranje (pred)stečajnog postupka, dužnikovu namjeru uopće nije potrebno dokazivati (čl. 202. st. 3. SZ-a). Njegova se namjera u tom slučaju presumira ${ }^{62}$, a presumira se i da je bliska osoba za tu njegovu namjeru znala ili morala znati.

U skladu sa zakonskom definicijom, bliskim osobama dužnika pravne osobe smatraju se (1) članovi upravnih i (2) nadzornih tijela dužnika, (3) osobno odgovorni članovi dužnika, (4) osobe koje u kapitalu dužnika sudjeluju s više od 25 \% kao i (5) osobe ili društva koji zbog svoje "položajno-pravne ili radnougovorne veze" s dužnikom imaju mogućnost biti upoznati s njegovim gospodarskim položajem. Ako koja od spomenutih fizičkih osoba nije zakonom obvezana čuvati

58 VTS, P̌̌-3901/02-3 od 28. lipnja 2005.; VTS, P̌̌-6913/03-4 od 24. listopada 2006.; VSRH, Revt 97/10-2 od 23. ožujka 2011.

59 Ede/Hirte, u: Hirte; Vallender (ur.), op. cit. u bilj. 5, § 130/239; Henckel, op. cit. u bilj. 17, § 129/109. Tako i VTS, P̌̌-4076/10-3 od 10. srpnja 2013. i VSRH, Revt 78/14-2 od 11. listopada 2017.

VTS, P̌̌-8315/2015-3 od 28. ožujka 2018.

61 VSRH, Revt 103/05-2 od 18. listopada 2005; VSRH, Revt 125/06-2 od 13. lipnja 2007.; VTS, Pž-2502/05-3 od 27. veljače 2008.; VSRH, Revt 301/11-2 od 10. veljače 2016 .

VTS, P̌̌-6380/03-4 od 24. listopada 2006.; Bork, op. cit. u bilj. 16, str. 137. 
tajnu o poslovima dužnika, krug se bliskih osoba proširuje i na (6) sve osobe koje su s njome u kakvoj osobnoj vezi, dakle s njome u braku ${ }^{63}$, izvanbračnoj zajednici, životnom partnerstvu, krvnom ili tazbinskom srodstvu ${ }^{64}$ ili pak s njome žive u zajedničkom kućanstvu ${ }^{65}$ (čl. 207. SZ-a). ${ }^{66}$

O naplatnom je ugovoru riječ ako se za činidbu traži protučinidba, koja mora biti veća od "neznatne" (arg. ex čl. 203. SZ-a). ${ }^{67}$ Naime, ako bi druga ugovorna strana dobila kakvu "neznatnu" naknadu, pravnu bi se radnju moglo pobijati kao da te naknade nije ni bilo, kao da je besplatna. Sudovi su ocijenili da se cijena jednaka $54 \%$ procijenjene vrijednosti nekretnine ne može smatrati neznatnom naknadom. ${ }^{68} \mathrm{~S}$ druge strane, prodaja vozila po cijeni nižoj od $10 \%$ njegove procijenjene vrijednosti je radnja poduzeta uz neznatnu naknadu. ${ }^{69} \mathrm{Za}$ ocjenu je li riječ o naplatnom pravnom poslu "nije važno na koji način i kada se činidba i protučinidba daju."70 Uzajamne činidbe, dakle, ne moraju biti istovremene. Međutim, naknadno ugovaranje ili davanje protuvrijednosti neće izmijeniti narav izvorno besplatne pravne radnje. ${ }^{71}$

63 Bliskima se smatraju i osobe s kojima je brak sklopljen tek nakon poduzete pravne radnje kao i osobe s kojima je brak prestao u posljednjoj godini prije poduzimanja radnje. Isto mutatis mutandis vrijedi i za izvanbračnu zajednicu i životno partnerstvo (čl. 207. st. 1. t. 1. SZ-a).

64 Bliskima se smatraju svi krvni srodnici u ravnoj liniji, (polu)braća i (polu)sestre te osobe, ali i svi takvi srodnici njezina bračnog druga (vjerojatno i izvanbračnog druga i životnog partnera, koji su ovdje u zakonu, vjerojatno omaškom, ispušteni). Bliskima se smatraju i (izvan)bračni drugovi te životni partneri svih tih srodnika (čl. 207. st. 1. t. 2. SZ-a).

65 Bliskima se smatraju osobe koje žive ili su u godini koja je prethodila poduzimanju radnje živjele u kućanstvu s tom osobom (čl. 207. st. 1. t. 3. SZ-a). To bi vjerojatno trebalo shvatiti kao da se bliskima smatraju sve one osobe koje su s tom osobom živjele $u$ vrijeme poduzimanja suspektne radnje ili u godini koja je prethodila poduzimanju te radnje, neovisno o tome što naknadno, u vrijeme pobijajuće parnice npr., više možda ne žive zajedno.

66 Bliskim osobama dužnika pojedinca smatraju se sve osobe na koje upućuje oznaka (6) u potonjoj rečenici, uključujući bilješke.

67 V. amplius infra poglavlje 3. Besplatnost pravne radnje. Ganter/Weinland, u: Schmidt (ur.), op. cit. u bilj. 5, § 134/23-25.

68 VSRH, Revt 127/11-2 od 3. srpnja 2013.

69 VTS, Pž-4810/06-3 od 16. rujna 2008.

70 VSRH, Revt 310/10-2 od 12. ožujka 2013.

71 Huber, M., Anfechtungsgesetz (AnfG). Gesetz über die Anfechtung von Rechtshandlungen eines Schuldners außerhalb des Insolvenzverfahrens, C. H. Beck, ${ }^{11} 2016 ., \S 4 / 20$. Slično i Čuveljak, op. cit. u bilj. 12, str. 669. 
Dakle, da pojasnimo, ako je naplatni ugovor kojim se vjerovnici izravno oštećuju sklopljen s bliskom osobom u razdoblju od dvije godine prije podnošenja prijedloga za otvaranje (pred)stečajnog postupka, pobijatelju je dokazivanje da je riječ o pobojnom ugovoru uvelike olakšano. ${ }^{72}$ To, međutim, ne znači da se takve ugovore ne bi moglo pobijati i ako su sklopljeni u razdoblju koje više od dvije godine prethodi podnošenju prijedloga za otvaranje (pred)stečajnog postupka. To je svakako moguće ${ }^{73}$, ali tada uz dokazivanje svih pretpostavaka namjernog oštećenja vjerovnika, pri čemu će izravno oštećenje i ugovor s bliskom osobom poslužiti kao vrlo jaki indiciji namjere oštećenja vjerovnika.

Besplatnost pravne radnje. I besplatne pravne radnje i radnje uz neznatnu naknadu mogu sugerirati da je stečajni dužnik namjeravao oštetiti svoje vjerovnike. Takve radnje će se, doduše, u pravilu pobijati kao pravne radnje bez naknade ili uz neznatnu naknadu, za što se ne traži dokazivanje dužnikove namjere (čl. 203. SZ-a). Ipak, i kod takvih će radnji biti nužno dokazivati dužnikovu namjeru ako nije ispunjena koja od pretpostavaka za tu posebnu osnovu pobijanja, posebice ako je besplatna pravna radnja poduzeta u kritičnom razdoblju koje više od četiri godine prethodi podnošenju prijedloga za otvaranje (pred) stečajnog postupka (arg. ex contrario iz loše sročene odredbe čl. 203. st. 1. SZ-a).

Dokazivanje dužnikove namjere tražit će se i u situacijama u kojima je stečajni dužnik dao sredstvo osiguranja da bi protivnik pobijanja kreditirao neku treću osobu. Iako se može reći da u tom slučaju stečajni dužnik nije dobio ništa, ipak nije riječ o radnji bez naknade u smislu čl. 203. SZ-a jer je protivnik pobijanja zauzvrat kreditirao treću osobu. ${ }^{74} \mathrm{Za}$ ocjenu je li riječ o naplatnoj pravnoj radnji odlučujuće je, naime, je li protivnik pobijanja, bilo kao vjerovnik bilo kao dužnik obveze, učinio kakvu imovinsku žrtvu. ${ }^{75}$ Okolnost da je radnja

72 Tako i Čuveljak, op. cit. u bilj. 12, str. 654.

73 Drukčije, čini se, VSRH, Revt 310/10-2 od 12. ožujka 2013. i Čuveljak, op. cit. u bilj. 12 , str. 654 , s čime se ne bi trebalo složiti.

74 Tako VTS, P̌̌-4280/02-3 od 21. lipnja 2005.; VTS, Pž-7191/02-4 od 19. rujna 2006.; VSRH, Revt 44/06-2 od 28. ožujka 2007.; VSRH, Revt 65/07-2 od 3. listopada 2007.; VTS, P̌̌-4091/05-3 od 30. listopada 2007; VSRH, Revt 45/12-2 od 12. veljače 2013.; VTS, P̌̌-2810/2015-2 od 26. travnja 2017. Drukčije, međutim, VTS, P̌̌-6902/03-5 od 15. studenog 2006.; VTS, P̌̌-8680/12-3 od 18. srpnja 2014. Tako, čini se, i Maržić, D., Pobijanje pravnih radnji bez naknade (čl. 132. Stečajnog zakona) u odnosu na institute hipoteke i jamstva, Pravo i porezi, vol. 12, br. 1, 2003., str. 19.

75 Zato, ako je dužnik vjerovniku dao naknadno osiguranje iako to nije bio dužan i usprkos tomu što on ili druga osoba nisu dobili odgovarajuću protuvrijednost, riječ je o besplatnoj pravnoj radnji. Huber, op. cit. u bilj. 71, § 4/19, 27. 
iz dužnikove perspektive besplatna služi ipak kao jak indicij njegove namjere oštećenja vjerovnika. ${ }^{76}$

Bliskost s protivnikom pobijanja. Jedan od mogućih indicija namjere je i okolnost da su stečajni dužnik i protivnik pobijanja bliske osobe. ${ }^{77}$ Iskustvo, naime, pokazuje da je dužnik sa sebi bliskim osobama nerijetko spreman surađivati i na štetu ostalih vjerovnika. ${ }^{78}$ Koliko god da definicija bliskih osoba iz čl. 207. SZ-a ${ }^{79}$ tu može biti od pomoći, sudovi ovdje njome nisu vezani, nego su ovlašteni prema slobodnoj ocjeni prosuditi koliko određeni stupanj bliskosti indicira namjeru oštećenja vjerovnika.

Ekvivalentnost uzajamnih činidaba. Jednaka vrijednost činidbe i protučinidbe kao i uobičajene ugovorne odredbe sugeriraju da stečajni dužnik nije namjeravao oštetiti vjerovnike. Sudovi su tako nalazili da nije bilo namjere oštećenja vjerovnika kad su vrijednosti činidbe i protučinidbe odgovarajuće ${ }^{80}$, kad je očito da je stečajni dužnik nastojao postići što višu cijenu za prodaju nekretnine preko javnih natječaja ${ }^{81}$ i kad je dužnik dao sredstvo osiguranja vraćanja kredita pod uobičajenim uvjetima. ${ }^{82}$

Tek je iznimno zamislivo da jednaka vrijednost uzajamnih činidaba ne isključuje namjeru. Vrhovni je sud tako našao da je dužnik namjeravao oštetiti svoje vjerovnike, iako je kupoprodajnim ugovorom predviđena odgovarajuća cijena, jer je protivnik pobijanja svoju obvezu isplate cijene namirio prijebojem. ${ }^{83}$

76 Tako VTS, Pž-201/03-3 od 7. studenog 2006., gdje je dužnikov fiducijarni prijenos nekretnina kao sredstvo osiguranja za reprogram kredita treće osobe uspješno pobijen po osnovi namjernog oštećenja. Slično, izgleda, i VTS, Pž-6797/04-3 od 4. listopada 2005.

77 Npr. VTS, Pž-2982/98 od 26. siječnja 1999., gdje je protivnik pobijanja "praktično ugovore sklapao sam sa sobom” ili VTS, Pž-572/04-3 od 7. ožujka 2007., gdje su stečajni dužnik i protivnik pobijanja društva istoga koncerna.

78 Cf. Bork, op. cit. u bilj. 16, str. 138.

79 V. supra poglavlje 3. Izravno oštećenje naplatnim ugovorom s bliskom osobom.

80 VSRH, II Rev 127/01-2 od 10. prosinca 2002.; VTS, Pž-2182/02 od 14. lipnja 2005.; VSRH, Revt 146/06-2 od 16. svibnja 2007.; VTS, P̌̌-555/2016-2 od 31. svibnja 2017.

81 VTS, P̌̌-7184/2016-6 od 28. lipnja 2017.

82 VTS, Pž-2182/02 od 14. lipnja 2005.

83 VSRH, Revt 42/06-2 od 5. travnja 2006. Odluka nije bez zamjerki. Prvo, iz oduke nije vidljivo je li namjera prijeboja, a time i oštećenja vjerovnika, postojala već u trenutku sklapanja kupoprodajnog ugovora, što je sud svakako trebao utvrditi. Drugo, nije jasno je li do oštećenja vjerovnika uopće došlo. Naime, ako je stečajni vjerovnik mogućnost prijeboja stekao pobojnom pravnom radnjom, prijeboj nije dopušten 
To je, uostalom, i razlog zašto se gotovinski posao, kojim dužnik za svoju činidbu prima protučinidbu jednake vrijednosti koja je izravno ušla u njegovu imovinu, može pobijati samo kao namjerno oštećenje (čl. 211. SZ-a). ${ }^{84} \mathrm{Kad}$ bi, primjerice, stečajni dužnik prodao svoju nekretninu po tržišnoj cijeni namjeravajući sakriti tako stečeni novac od svojih vjerovnika, ugovor o kupoprodaji bi, uz ispunjenje svih ostalih pretpostavaka, mogao biti pobojan..$^{85}$

Neuobičajene ugovorne odredbe nepovoljne za dužnika. Namjeru oštećenja vjerovnika indiciraju i neuobičajene ugovorne odredbe objektivno nepovoljne za dužnika. Sudovi su tako našli da je dužnikova namjera vidljiva iz ugovorne odredbe da će se kupoprodajna cijena dužniku djelomično namiriti preuzimanjem njegova duga, a djelomično asignacijom, prijebojem ili na drugi način koji odabere protivnik pobijanja. ${ }^{86}$ Namjera je bila razvidna i iz okolnosti što je dužnik unaprijed, već u kupoprodajnom ugovoru, pristao da protivnik pobijanja kupoprodajnu cijenu namiri prijebojem. ${ }^{87} \mathrm{O}$ namjeri oštećenja vjerovnika sudovi su zaključivali i iz činjenice da je dužnik dopustio prijenos vlasništva na nekretnini prije isplate kupoprodajne cijene ${ }^{88}$ i iz okolnosti da kupoprodajni ugovor nije slijedio uvjete natječaja, među ostalim, u vezi s predmetom, cijenom i načinom plaćanja. ${ }^{89}$

(Prijeteća) insolventnost dužnika. Posebnu pažnju kao indicij namjere oštećenja vjerovnika zaslužuje (prijeteća) insolventnost dužnika. To, uostalom,

(čl. 176. st. 1. t. 4. SZ-a), što znači da ex lege ne proizvodi učinke. Protivnik pobijanja bi, dakle, i dalje bio dužan platiti kupoprodajnu cijenu. Stečajni vjerovnici stoga nisu nužno u lošijem položaju nego što bi bili da je ugovor o kupoprodaji pobijen (ako je, dakako, ugovorena cijena odgovarajuća kao što je utvrdio sud).

Tako i VTS, Pž-5003/2001 od 19. ožujka 2002.; VTS, Pž-945/05-3 od 21. veljače 2006.; VTS, P̌̌-1496/03-3 od 29. kolovoza 2006.; VTS, P̌̌-3069/06-3 od 26. kolovoza 2009.; VTS, Pž-4863/2013-3 od 15. ožujka 2017. O gotovinskom poslu v. amplius Dika, op. cit. u bilj. 3, str. 166 sq.; Wagner, u: Kummer et al. (ur.), op. cit. u bilj. 5, str. 810 sqq.; Henckel, op. cit. u bilj. 17, str. 443 sqq.

85 Tu mogućnost, čini se, ne uočava Pavlović, op. cit. u bilj. 8, poglavlje 4.8 .

VSRH, Revt 5/08-2 od 14. siječnja 2009.

VTS, Pž-6913/03-4 od 24. listopada 2006.; VTS, Pž-7312/04-3 od 2. listopada 2007. Valja napomenuti da bi se kupoprodajni ugovor mogao pobijati samo ako je već u njemu bilo predviđeno da protivnik pobijanja može steći vlasništvo prije isplate cijene. Ako pak ugovorom to nije bilo predviđeno, nego je stečajni dužnik nakon sklapanja kupoprodajnog ugovora, a prije isplate cijene, prenio vlasništvo na nekretnini, pobijati bi se mogao samo posao prijenosa vlasništva, kao radnja inkongruentna pokrića. 
proizlazi i iz presumpcije prema kojoj se znanje protivnika pobijanja za namjeru pretpostavlja ako je on znao da dužniku prijeti nesposobnost za plaćanje i da se radnjom oštećuju vjerovnici (čl. 202. st. 1 . SZ-a). ${ }^{90}$ Ne začuđuje stoga da se u veliku broju odluka dužnikova namjera oštećenja vjerovnika iščitava upravo iz njegove nesposobnosti za plaćanje. ${ }^{11}$ Pojam (prijeteće) nesposobnosti za plaćanje podudara se pritom s istoimenim stečajnim razlozima iz čl. 4. i 6. SZ-a. ${ }^{92} \mathrm{Ne}$ bi, dakle, bilo dovoljno da je dužnik bio samo u lošem financijskom stanju ${ }^{93}$ iako bi se moglo postaviti pitanje koje je praktično razgraničenje između prijeteće nesposobnosti za plaćanje i loše financijske situacije. Naime, zakonska presumpcija o prijetećoj nesposobnosti za plaćanje iz čl. 4. st. 2. SZ-a ${ }^{44}$ tek je jedan od načina dokazivanja da dužnik do dospijeća neće moći ispuniti svoje postojeće obveze (čl. 4. st. 1. SZ-a) tako da bi se i iz nekih drugih pokazatelja dužnikove loše financijske situacije moglo zaključivati da mu ujedno i prijeti insolventnost.

Sudovi katkad idu tako daleko da prijeteću nesposobnost za plaćanje tretiraju kao nužnu pretpostavku za postojanje dužnikove namjere. “Da bi dužnik poduzeo radnju s namjerom oštećenja vjerovnika na strani dužnika treba najmanje prijetiti nesposobnost za plaćanje." 95 Isto tako, sud je bio zaključio da stečajni dužnik, usprkos tomu što je inkongruentno namirio blisku osobu, nije djelovao s namjerom jer "u vrijeme sklapanja ugovora nije bio insolventan, niti mu je u to vrijeme prijetila nesposobnost za plaćanje". ${ }^{96}$ Isto tako, sud je našao da, iako je ugovor sklopljen bez naknade, nije bilo namjere oštećenja vjerovnika jer je stečajni dužnik u vrijeme poduzimanja suspektne radnje "poslovao pozi-

$90 \quad$ V. infra poglavlje 4.

91 VSRH, Rev 147/01-2 od 14. siječnja 2003.; VTS, Pž-6013/02 od 13. listopada 2004.; VTS, P̌̌-7427/04-3 od 12. srpnja 2005.; VSRH, Revt 90/05-2 od 5. listopada 2005.; VSRH, Revt 19/05-2 od 29. studenog 2005.; VTS, P̌̌-6159/05-3 od 21. listopada 2008.; VSRH, Revt 82/09-2 od 21. svibnja 2009.; VSRH, Revt 362/13-2 od 3. studenog 2016.; VSRH, Revt 134/12-2 od 16. studenoga 2016.; VSRH, Revt 461/20163 od 15. svibnja 2019.

92 Tako Ede/Hirte, u: Hirte; Vallender (ur.), op. cit. u bilj. 5, § 130/39; Ganter/Weinland, u: Schmidt (ur.), op. cit. u bilj. 5, § 130/44, za njemačko pravo.

93 Cf. VSRH, Gzz-296/2003-2 od 22. rujna 2004.; VTS, Pž-7363/04-3 od 21. veljače 2006.

94 Smatrat će se da dužniku prijeti nesposobnost za plaćanje ako (još) nije insolventan i ako u Očevidniku redoslijeda osnova za plaćanje koji vodi Financijska agencija ima jednu ili više evidentiranih neizvršenih osnova za plaćanje, koje je trebalo bez daljnjeg pristanka dužnika naplatiti s bilo kojeg od njegovih računa, ili pak više od 30 dana kasni s isplatom plaće radniku ili na plaću ne uplati doprinose i poreze.

95 VSRH, Revt 379/15-2 od 21. studenog 2017.

96 VSRH, Revt 127/11-2 od 3. srpnja 2013. 
tivno i svojim vjerovnicima uredno podmirivao dospjele obveze." ${ }^{97} \mathrm{~S}$ takvom se praksom ne bi trebalo složiti. Okolnost da dužnik nije bio nesposoban za plaćanje ne isključuje ipso facto namjeru oštećenja vjerovnika. Ne traži se, naime, namjera uzrokovanja ili produbljenja stečajnih razloga. Stečajni je dužnik mogao namjerno oštetiti svoje vjerovnike i prije nego što mu je uopće zaprijetila nesposobnost za plaćanje.

Oprez valja primijeniti i u drugom smjeru. Okolnost da je dužnik bio nesposoban za plaćanje ne znači nužno da je namjeravao oštetiti vjerovnike. Olako zaključivanje o namjeri oštećenja iz činjenice dužnikove insolventnosti ili prijeteće insolventnosti dovelo bi do paralize ili barem ugroze dužnikova daljnjeg poslovanja jer bi svaka njegova iduća radnja bila pobojna. Nitko mu više ne bi davao kredit iz bojazni da će sredstvo osiguranja kojim je osigurao povrat kredita biti bez učinaka. Čim bi postao nesposoban za plaćanje, dužnik bi ušao u začarani krug i nužno bi slijedila njegova propast.

Upravo zato treba pomno razmotriti nije li u vrijeme (prijeteće) nesposobnosti za plaćanje pojedina radnja poduzeta upravo da bi otklonila tu nesposobnost. Pritom nije odlučujuće je li takva radnja bila uspješna pa čak ni je li bilo vjerojatno da će biti uspješna. ${ }^{98}$ Dovoljno je da se može razumno pretpostaviti da je dužnik poduzeo tu radnju s namjerom izlaska iz krize. U tom kontekstu i relativno rizična radnja nije poduzeta s namjerom oštećenja ako dužnik nije imao drugih opcija i ako se mogao barem nadati da će ona imati povoljne učinke. Protivno bi shvaćanje moglo ozbiljno ugroziti da kreditne institucije uopće daju kredite radi sanacije poduzeća.

Treba se stoga složiti s odlukama u kojima su sudovi prepoznali da dužnikova namjera sanacije isključuje namjeru oštećenja vjerovnika. Primjerice, usprkos tomu što su vjerovnici bili oštećeni ugovorom o fiducijarnom prijenosu vlasništva u kojemu nije postojala ekvivalentnost činidaba, i stečajni dužnik i banka imali su zapravo namjeru "omogućiti stečajnom dužniku vraćanje kredita jer stečajni dužnik bez zaduživanja nije mogao servisirati svoje dospjele obveze." 99 "Namjera oštećenja (...) nedostaje onda kada je dužnik svjestan da je pokušaj saniranja

97 VTS, P̌̌-8680/12-3 od 18. srpnja 2014.

98 Zato se ne bi trebalo bezuvjetno složiti sa zaključkom VTS-a u odluci P̌̌-572/04-3 od 7. ožujka 2007. da su "tvrdnje o namjeri spašavanja proizvodnje tuženika i neuspješnom pokušaju sanacije (su) potpuno irelevantne. Do spašavanja proizvodnje tuženika i sanacije nije došlo." Isto vrijedi i za odluku istog suda Pž-7427/04-3 od 12. srpnja 2005. gdje je sud našao da kredit nije dan u svrhu sanacije "upravo zato što su i nadalje postojali uvjeti za otvaranje stečajnog postupka nad tužiteljem”. 
opterećen rizikom, ali su nastojanja da se društvo spasi u prvom planu." ${ }^{100}$ Isto tako, sama činjenica da u trenutku kad neko poduzeće zapadne u financijske teškoće, ono plati nekom od svojih vjerovnika dužni iznos ne upućuje na namjeru oštećenja drugih vjerovnika, već trebaju biti utvrđene i druge činjenice koje upućuju na takvu namjeru. ${ }^{101}$

Uostalom, kad bi se nesposobnost za plaćanje izjednačila s namjerom oštećenja, namjerno bi se oštećenje suviše približilo trima zasebnim osnovama pobijanja koje se i temelje na objektivnoj okolnosti da je dužnik nesposoban za plaćanje (kongruentno i inkongruentno pokriće te izravno oštećenje) te bi one izgubile svoj smisao. Ne bi se, naime, smjelo dogoditi da se olako zaključuje da je, primjerice, svako inkongruentno pokriće poduzeto u razdoblju koje više od tri mjeseca prethodi podnošenju prijedloga za pokretanje (pred)stečajnog postupka namjerno oštećenje vjerovnika. Sve indicije treba pomno razmotriti u okolnostima konkretnog slučaja.

\section{ZNANJE PROTIVNIKA POBIJANJA O DUŽNIKOVOJ NAMJERI OŠTEĆENJA VJEROVNIKA}

Da bi dužnikovo namjerno oštećenje vjerovnika bilo uspješno pobijeno, u pobijajućoj se parnici mora dokazati i da je protivnik pobijanja u vrijeme poduzimanja radnje za takvu dužnikovu namjeru znao (čl. 202. st. 1. SZ-a). Znanje protivnika pobijanja po stupnju svijesti odgovara znanju stečajnog dužnika. Kod protivnika pobijanja se, međutim, ne traži i voljni element pa se ne govori o namjeri nego (samo) o njegovu znanju. Time što je protivnik pobijanja znao za dužnikovu namjeru izgubio je, uvjetno rečeno, moralno pravo na zaštitu od dužnika stečenih imovinskih prava.

Dužnikova namjera oštećenja vjerovnika i znanje protivnika pobijanja o toj namjeri u pravilu će se utvrđivati na temelju istih činjenica. ${ }^{102}$ Odraz takva shvaćanja je i oboriva zakonska presumpcija prema kojoj se znanje protivnika pobijanja o dužnikovoj namjeri pretpostavlja ako je on znao da dužniku prijeti nesposobnost za plaćanje i da se radnjom oštećuju vjerovnici (čl. 202. st. 1. SZ-a). ${ }^{103}$

100 Ibid.

101 VSRH, Revt 146/06-2 od 16. svibnja 2007.

102 Kayser/Freudenberg, u: Stürner et al., op. cit. u bilj. 5, § 133/19, 26, 38. Slično i VSRH, Revt-19/05-2 od 29. studenog 2005.

103 Presumpciju bi se moglo oboriti dokazom da je protivnik pobijanja imao razloga smatrati da je stečajni dužnik poduzeo radnju radi sanacije poduzeća ili u kakvu drugu legitimnu svrhu. 
Znanje za dužnikovu (prijeteću) insolventnost. Znanje o prijetećoj nesposobnosti za plaćanje i znanje o oštećenju vjerovnika kumulativno ${ }^{104}$ čine bazu izložene oborive presumpcije. U praksi će, međutim, najčešće biti dovoljno dokazati da je protivnik pobijanja znao da dužniku prijeti nesposobnost za plaćanje. Naime, ako protivnik pobijanja zna da dužniku, koji sudjeluje u pravnom prometu i ima više vjerovnika, prijeti nesposobnost za plaćanje, onda zna i da se poduzetom radnjom oštećuju ostali vjerovnici. ${ }^{105}$ Bilo bi pretjerano tražiti da protivnik pobijanja zna točnu vrijednost dužnikove imovine i ukupnu visinu njegovih dugova. Nije, međutim, dovoljno dokazati da je protivnik pobijanja samo znao za loše financijsko stanje dužnika. ${ }^{106}$ I ovdje bi se, međutim, moglo postaviti pitanje koje je praktično razgraničenje između prijeteće nesposobnosti za plaćanje i loše financijske situacije. ${ }^{107}$

U sudskoj praksi u nemalu broju slučajeva o znanju protivnika pobijanja o dužnikovoj namjeri oštećenja vjerovnika zaključuje se upravo na temelju presumpcije iz čl. 202. st. 1. SZ-a. ${ }^{108}$ Štoviše, čini se da se sudovi na nju i previše oslanjaju pa iz okolnosti da dužnik nije bio nesposoban za plaćanje ili da protivnik pobijanja za to nije znao umah zaključuju da protivnik pobijanja nije znao ni za dužnikovu namjeru oštećenja. ${ }^{109} \mathrm{~S}$ time se ne bi trebalo složiti. Nije, naime, teško zamisliti da je kupac koji je od stečajnog dužnika kupio nekretninu upola cijene znao za dužnikovu namjeru oštećenja vjerovnika iako dužniku u trenutku sklapanja toga ugovora još nije prijetila nesposobnost za plaćanje. Ne treba zaboraviti da je ipak riječ o kritičnom razdoblju od čak deset godina prije podnošenja prijedloga za otvaranje (pred)stečajnog postupka i da je kod pobijanja namjernog oštećenja vjerovnika u prvom planu sankcioniranje fraudolozna dužnikova postupanja. Moguće je, naime, da je dužnik koji je namjerno oštetio

104 Tako i VTS, Pž-7363/04-3 od 21. veljače 2006.

105 Bork, u: Kübler; Prütting; Bork (ur.), op. cit. u bilj. 5, § 133/62. VTS, Pž-6013/02 od 13. listopada 2004.; VSRH, Revt 42/06-2 od 5. travnja 2006.; VSRH, Revt 461/2016-3 od 15. svibnja 2019., gdje su se sudovi orijentirali isključivo na znanje protivnika pobijanja o dužnikovoj nesposobnosti za plaćanje, bez posebne analize njegova znanja o oštećenju vjerovnika.

106 Tako VTS, P̌̌-7363/04-3 od 21. veljače 2006.

107 V. supra poglavlje 3. (Prijeteća) insolventnost dužnika.

108 Npr. VSRH, Revt 5/08-2 od 14. siječnja 2009.; VSRH, Revt 97/10-2 od 23. ožujka 2011.; VSRH, Revt 45/12-2 od 12. veljače 2013.; VSRH, Revt 461/2016-3 od 15. svibnja 2019; VSRH, Revt 364/2014-2 od 24. lipnja 2020.

109 Npr. VTS, P̌̌-7363/04-3 od 21. veljače 2006.; VSRH, Revt 138/07-2 od 3. veljače 2010.; VSRH, Revt 45/12-2 od 12. veljače 2013. 
svoje vjerovnike još godinama uspješno poslovao prije negoli je nad njim otvoren stečajni postupak. ${ }^{110}$

Praktično gledano, najvažnija razlika između stanja svijesti stečajnog dužnika i protivnika pobijanja je njihova različita mogućnost saznanja za dužnikovu (prijeteću) nesposobnost za plaćanje. Dok će dužnik, po naravi stvari, gotovo uvijek znati da mu prijeti nesposobnost za plaćanje, protivnik pobijanja s time ne mora biti upoznat. Nameće se zato pitanje s kojim bi stupnjem sigurnosti trebalo utvrditi da je protivnik pobijanja znao za dužnikovu nesposobnost za plaćanje.

Iz još jedne se, ovaj put neoborive, zakonske presumpcije može zaključiti da je dostatno dokazati da je protivnik pobijanja morao znati za okolnosti iz kojih se nužno moralo zaključiti da je dužnik nesposoban za plaćanje i da se radnjom oštećuju vjerovnici (čl. 202. st. 2. SZ-a). Zakonska formulacija te presumpcije nije, međutim, najs(p)retnija. Ponajprije, izraz vjerovnik iz te bi presumpcije ("smatrat će se da je vjerovnik znao da dužniku prijeti nesposobnost za plaćanje i da se radnjom oštećuju vjerovnici ...") trebalo shvatiti u smislu druga strana, odnosno protivnik pobijanja. ${ }^{111}$ Nadalje, upitno je i koliko je oportuna konstrukcija od dviju ulančanih presumpcija od kojih druga, neoboriva, pomaže pojasniti prvu, oborivu presumpciju.

Nejasno je i što se tom neoborivom presumpcijom zapravo postiže. Ona znanje protivnika pobijanja da dužniku prijeti nesposobnost za plaćanje i da se radnjom oštećuju vjerovnici izvodi iz okolnosti iz kojih se "nužno moralo zaključiti" da je dužnik nesposoban za plaćanje i da se radnjom oštećuju vjerovnici. Riječ je o cirkularnom zaključivanju. Ako se iz okolnosti nešto "nužno moralo zaključiti", onda nema nikakve potrebe za dodatnom presumpcijom. Vrijedi i obrnuto. Ako postoji i najmanja sumnja, neće se raditi o okolnostima iz kojih se nešto "nužno moralo zaključiti” pa sudovi od te presumpcije neće imati koristi.

Ispada, dakle, da je jedini novum te presumpcije to što je dovoljno da je protivnik pobijanja za te okolnosti morao znati. Ako je to zaista bila intencija zakonodavca ${ }^{112}$, bilo bi bolje da je to uneseno u osnovnu presumpciju iz čl. 202. st. 1. SZ-a te da ona glasi da se znanje za namjeru pretpostavlja "ako je druga

110 Bilić, op. cit. u bilj. 6, str. 340 .

111 Do previda u formulaciji presumpcije došlo je vjerojatno jer je čl. 202. st. 2. SZ-a po svoj prilici oblikovan po uzoru na presumpciju o znanju protivnika pobijanja kongruentna pokrića iz čl. 199. st. 3. SZ-a. Međutim, kongruentno pokriće pretpostavlja da je namirena ili osigurana obveza upravo stečajnog vjerovnika (čl. 199. st. 1. SZ-a), što kod namjernog oštećenja ne mora biti slučaj.

112 Cf. Dika, op. cit. u bilj. 3, str. 188; Pavlović, op. cit. u bilj. 8, poglavlje 4.3. 
strana znala ili morala znati da dužniku prijeti nesposobnost za plaćanje i da se radnjom oštećuju vjerovnici”.

Bliskost s dužnikom. Brojni su indiciji na temelju kojih sudska praksa zaključuje da je protivnik pobijanja znao ili morao znati za dužnikovu (prijeteću) nesposobnost za plaćanje ili da je na drugi način znao za dužnikovu namjeru oštećenja vjerovnika. Jedan od najčešćih indicija je okolnost da je protivnik pobijanja bio osoba bliska stečajnom dužniku, o čemu je već supra bilo riječi. ${ }^{113}$ Iako se u kontekstu namjernog oštećenja iz čl. 202. st. 1. i 2. SZ-a zakonom ne presumira znanje bliske osobe ${ }^{114}$, pravila iskustva govore da će bliske osobe često biti upućene u dužnikovo financijsko stanje i njegove namjere.

Sudovi su o znanju protivnika pobijanja zaključivali na temelju činjenice da je protivnik pobijanja bio član u društvu stečajnom dužniku ${ }^{115}$, da je stečajni dužnik bio jedini član u društvu protivniku pobijanja ${ }^{116}$, da je protivnik pobijanja ili osoba koja je djelovala u njegovo ime bila član organa stečajnog dužnika $a^{117}$ i iz činjenice da je protivnik pobijanja bio zaposlenik stečajnog dužnika, a njegova supruga "zakonski zastupnik" drugog protivnika pobijanja. ${ }^{118} \mathrm{~S}$ druge strane, osoba koja je članom uprave prestala biti prije više od jedne godine prije poduzimanja pobojne pravne radnje ne može se smatrati bliskom osobom kao da je i nadalje član uprave. ${ }^{119}$ Valja ovdje napomenuti da je sud, ako to ocijeni potrebnim, slobodan definirati bliskost osoba i na drugačiji način negoli to proizlazi iz zakonske definicije bliskih osoba u čl. 207. SZ-a.

Poslovna suradnja, medijski napisi i “problemi” s ispunjenjem. O znanju protivnika pobijanja često se zaključuje i na temelju njegove dugogodišnje poslovne suradnje sa stečajnim dužnikom, pogotovu ako postoje i dodatni indiciji. Sudovi su tako zaključili da je protivnik pobijanja znao za dužnikovu blokadu

113 V. supra poglavlje 3. Bliskost s protivnikom pobijanja.

114 Drukčije je, recimo, u čl. 202. st. 3. (namjerno izravno oštećenje naplatnim ugovorom s bliskom osobom), ali i u čl. 199. st. 4. (kongruentno pokriće), čl. 200. st. 2. (inkongruentno pokriće) i u čl. 201. st. 3. SZ-a (izravno oštećenje vjerovnika).

115 VSRH, Revt 90/05-2 od 5. listopada 2005.; VSRH, Revt 42/06-2 od 5. travnja 2006; VTS, P̌̌-572/04-3 od 7. ožujka 2007.; VSRH, Revt 155/07-2 od 28. listopada 2008.; VSRH, Revt 458/2017-3 od 26. veljače 2019.

116 VSRH, Revt 134/12-2 od 16. studenoga 2016.

117 VSRH, Revt 42/06-2 od 5. travnja 2006.; VTS, Pž-3260/04-6 od 8. prosinca 2006.; VSRH, Revt 157/07-2 od 19. ožujka 2008.; VSRH, Revt 5/08-2 od 14. siječnja 2009.; VSRH, Revt 97/10-2 od 23. ožujka 2011.; VSRH, Revt 461/2016-3 od 15. svibnja 2019.; VSRH, Revt 364/2014-2 od 24. lipnja 2020.

118 VSRH, Revt 362/13-2 od 3. studenog 2016.

119 VTS, Pž-4810/06-3 od 16. rujna 2008. 
jer su dugo godina surađivali i jer mu je reprogramirao dugove ${ }^{120}$ ili zato što su on i dužnik bili dugogodišnji partneri, a dužnikova je blokada bila općepoznata činjenica iz dnevnog tiska. ${ }^{121}$ I neovisno o dugogodišnjoj suradnji, široko dostupni medijski napisi o financijskoj krizi stečajnog dužnika također indiciraju znanje protivnika pobijanja. ${ }^{122} \mathrm{~S}$ druge strane, "sama činjenica višegodišnje poslovne suradnje, a bez utvrđenja da je tuženik znao za nelikvidnost, probleme u poslovanju tužitelja, sama po sebi ne dovodi do zaključka da su ispunjeni uvjeti za pobijanje pravne radnje dužnika."123

Znanje protivnika pobijanja za dužnikovu namjeru oštećenja vjerovnika indicira i to što mu dužnik nije plaćao ugovorenu cijenu te se opravdavao time da "u tom trenutku (...) nema novaca"124 kao i to što je protivnika pobijanja dužnik uputio da zbog blokade ne isplati ugovoreni iznos njemu nego nekoj trećoj osobi. ${ }^{125}$ Dovoljno je, također, da je protivnik pobijanja znao da se stečajni dužnik nalazi u financijskim poteškoćama i da je prenesena nekretnina jedina vrjednija dužnikova imovina. ${ }^{126}$ Isto tako, protivnik pobijanja znao je za dužnikovu lošu financijsku situaciju jer je s njim sklopio sudsku nagodbu kojom je ugovorena zamjena ispunjenja (datio in solutum). ${ }^{127}$

S druge strane, uobičajene ugovorne odredbe, primjerice uobičajeno osiguranje vraćanja kredita, sugeriraju da protivnik pobijanja nije znao za eventualnu dužnikovu namjeru oštećenja vjerovnika. ${ }^{128}$ Isto tako, okolnost da je nekretnina prodana na javnoj dražbi sugerira da ju je protivnik pobijanja kupio u dobroj vjeri. ${ }^{129}$ Sud je zaključio da protivnik pobijanja nije znao za nesposobnost za plaćanje i ako je financijska dokumentacija upućivala na dužnikovo likvidno poslovanje. ${ }^{130}$

\footnotetext{
120 VSRH, Revt 78/16-2 od 30. svibnja 2017.

121 VTS, P̌̌-411/06-6 18. svibnja 2010.

122 VTS, Pž-2954/05-3 od 19. kolovoza 2008.

123 VSRH, Revt 210/12-2 od 19. lipnja 2013.

124 VTS, P̌̌-7312/04-3 od 2. listopada 2007.

125 VTS, Pž-2954/05-3 od 19. kolovoza 2008. Slično i VSRH, Revt 102/05-2 od 16. ožujka 2006.

126 VSRH, Revt 131/07-2 od 3. prosinca 2008.

127 VSRH, II Rev 3/1992-2 od 1. travnja 1992.

128 VTS, P̌̌-2182/02 od 14. lipnja 2005.

129 VTS, Pž-4677/01 od 19. ožujka 2002., gdje je sud, doduše, razmatrao izravno oštećenje kao posebnu osnovu pobijanja, a ne namjerno oštećenje.

130 VSRH, Revt 45/12-2 od 12. veljače 2013.
} 
Profesionalna dužna pažnja protivnika pobijanja. Pri utvrđivanju znanja protivnika pobijanja sudovi se katkad služe i standardom dužne pažnje, iz kojega izvode da je protivnik pobijanja morao znati za dužnikovu (prijeteću) nesposobnost za plaćanje. To je osobito izraženo kad je protivnik pobijanja profesionalac koji mora djelovati pažnjom dobrog stručnjaka (čl. 10. st. 2. ZOO-a). Banka bi tako trebala provjeriti kreditnu sposobnost svog klijenta. Zato bi iz činjenice da je dužnik bio u dugotrajnoj blokadi računa banka morala znati da je nesposoban za plaćanje $\mathrm{e}^{131}$, osobito ako je upravo ona vodila račune stečajnog dužnika. ${ }^{132}$ Tu nema dvojbe da je banka morala biti upoznata s njegovom eventualnom nesposobnošću za plaćanje.

Sudovi su, međutim, iz bančine dužnosti da ocijeni bonitet primatelja kredita znali izvesti i potpuno suprotan zaključak. Sud je tako našao da je upravo zbog nepovoljne ocjene boniteta primatelja kredita banka imala dužnost ugovoriti pobijano sredstvo osiguranja. Budući da je banka samo ispunjavala svoju dužnost, ne može se reći da je znala za dužnikovu namjeru oštećenja vjerovnika. ${ }^{133}$ S takvim se zaključkom ne bi trebalo složiti. Okolnost da banka ima dužnost osigurati rizične zajmove ne isključuje presumpciju bančina znanja za dužnikovu namjeru oštećenja vjerovnika. Kad bi to bio slučaj, nastala bi apsurdna situacija u kojoj, što su vjerovnici više oštećeni pojedinim sredstvom osiguranja, manja je vjerojatnost da će pobijanje uspjeti. To bi bila druga krajnost u odnosu na već opisani stav da svako sredstvo osiguranja dano za vrijeme dužnikove blokade nužno podrazumijeva dužnikovu namjeru oštećenja vjerovnika i znanje protivnika pobijanja za takvu namjeru. ${ }^{134}$

Standard profesionalne dužne pažnje katkad sudovi primjenjuju i na obične trgovce smatrajući da bi i oni bili dužni provjeriti bonitet založnog dužnika, osobito jer je on u blokadi dulje od tri godine. ${ }^{135} \mathrm{~S}$ tim bi trebalo biti vrlo oprezan. Običan trgovac, koji nije banka ili usporediva financijska institucija, načelno nema javnopravnu dužnost provjeravati bonitet svojih suugovaratelja. ${ }^{136} \check{C}$ ak i

131 VTS, Pž-7427/04-3 od 12. srpnja 2005.

132 VSRH, II Rev 5/1996-2 od 8. svibnja 1996.; VSRH, Revt 82/09-2 od 21. svibnja 2009., gdje, možda omaškom, sud koristi izraz "mogao znati”.

133 VTS, Pž-4204/06-3 od 18. studenog 2008.

134 V. supra poglavlje 3. (Prijeteća) insolventnost dužnika.

135 VTS, P̌̌-6159/05-3 od 21. listopada 2008., gdje protivnik pobijanja nije bio kreditna institucija.

136 Tako i VSRH, Revt 138/07-2 od 3. veljače 2010. 
ako bi se ona mogla izvesti iz, recimo, dužnosti upravljanja kreditnim rizikom ${ }^{137}$, povreda bi te dužnosti bila, po svoj prilici, obična, a ne krajnja nepažnja.

Čini se da sudovi katkad i olako zaključuju o znanju protivnika pobijanja. Naime, ne čini se uvjerljivim da je protivnik pobijanja znao za dužnikovu namjeru oštećenja zato što se osobe koje su kupnjom postale suvlasnici nekretnine sigurno poznaju otprije. ${ }^{138}$ Takvo zaključivanje se izgleda ne temelji na krajnjoj, nego na običnoj nepažnji. ${ }^{39}$ Isto tako, činjenica da se radilo o dugotrajnoj blokadi sama po sebi ne znači da je protivnik pobijanja za nju morao znati. ${ }^{140}$ Kao i kod indicija namjere, i indicije znanja protivnika pobijanja o toj namjeri treba ocjenjivati u cjelini konkretnog slučaja.

\section{ZAKLJUČAK}

Namjerno oštećenje vjerovnika stečajnog dužnika pobojno je u kritičnom razdoblju od čak deset godina prije podnošenja prijedloga za otvaranje (pred) stečajnog postupka pa sve do otvaranja stečajnog postupka. Dugo kritično razdoblje upućuje na to da je ovdje u prvom planu sankcioniranje fraudolozna postupanja stečajnog dužnika u dogovoru s protivnikom pobijanja, čak i ako do njega nije došlo u neposrednoj blizini otvaranja stečajnog postupka. Blizina otvaranja stečajnog postupka u vrijeme poduzimanja suspektne radnje samo je dodatan indicij da je radnja poduzeta s namjerom oštećenja vjerovnika. Moguće je, međutim, i da je dužnik koji je namjerno oštetio svoje vjerovnike još godinama uspješno poslovao prije negoli je nad njim otvoren stečajni postupak. Budući da su i stečajni dužnik i protivnik pobijanja svjesno sudjelovali u oštećenju vjerovnika, učinci njihove pravne radnje moraju ustuknuti pred legitimnim interesom namirenja vjerovnika iz stečajne mase.

Da bi, dakle, pobio dužnikovu pravnu radnju poduzetu s namjerom oštećenja vjerovnika, ovlašteni pobijatelj mora, uz opće pretpostavke pobijanja koje se trebaju dokazati kod svih osnova pobijanja predviđenih Stečajnim zakonom, dokazati i da je dužnik u propisanom kritičnom razdoblju pravnu radnju podu-

$137 C f$. čl. 7., osobito st. 4. Zakona o predstečajnoj nagodbi i financijskom poslovanju, Narodne novine, br. 108/12, 144/12, 81/13, 112/13, 78/15, 71/15.

138 VTS, P̌̌-6913/03-4 od 24. listopada 2006.

139 Sud je, doduše, u obzir uzeo i dodatan indicij, da je kupoprodajna cijena bila niža od tržišnih cijena za stanove na tom području. Kupoprodajna cijena bi, međutim, morala biti drastično niža od tržišne da bi se moglo govoriti o tome da je protivnik pobijanja morao znati za namjeru oštećenja vjerovnika.

140 Drukčije, čini se, VTS, P̌̌-6797/04-3 od 4. listopada 2005. 
zeo upravo s namjerom oštećenja svojih vjerovnika i da je protivnik pobijanja u vrijeme poduzimanja radnje za takvu dužnikovu namjeru znao (čl. 202. SZ-a). S obzirom na to da je te pretpostavke, koje se odnose na kvalificirane oblike svijesti, razmjerno teško dokazati, one se utvrđuju na temelju objektiviziranih, najčešće gospodarskih indicija i s njima povezanih zakonskih presumpcija.

Pobijanje namjernog oštećenja vjerovnika stečajnog dužnika u praksi je hrvatskih sudova razmjerno često. Iz te prakse proizlazi da su najvažniji indiciji dužnikove namjere oštećenja vjerovnika, a dijelom i znanja protivnika pobijanja za tu namjeru, inkongruentno pokriće, nejednaka vrijednost uzajamnih činidaba, neuobičajene ugovorne odredbe nepovoljne za dužnika, bliskost stečajnog dužnika i protivnika pobijanja te dužnikova (prijeteća) nesposobnost za plaćanje.

Pobliže, inkongruentno pokriće znači da je stečajni dužnik dao protivniku pobijanja osiguranje ili namirenje koje protivnik pobijanja nije imao pravo zahtijevati ili barem ne u to vrijeme i na taj način. Takvo djelovanje opravdano pobuđuje sumnju jer dužnik uobičajeno ne daje nešto što nije dužan. Vrijedi i obrnuto. Kongruentno pokriće, kod kojega je stečajni dužnik djelovao u skladu sa sadržajem svoje obveze, sugerira u pravilu da nije postojala namjera oštećenja vjerovnika. Drukčije bi eventualno moglo biti ako je dužniku prijetila ili ako je već nastupila nesposobnost za plaćanje, što bi moglo indicirati da je i radnja kongruentna pokrića poduzeta s namjerom oštećenja vjerovnika.

Nejednaka vrijednost činidbe i protučinidbe te neuobičajene ugovorne odredbe nepovoljne za dužnika također sugeriraju da su i dužnik i protivnik pobijanja bili svjesni oštećenja dužnikovih vjerovnika. S druge strane, namjera i znanje za namjeru najčešće su isključeni ako su ugovori sklopljeni u skladu s tržišnim uvjetima.

Bliska povezanost stečajnog dužnika i protivnika pobijanja povećava vjerojatnost da je dužnik namjeravao oštetiti vjerovnike upravo u korist protivnika pobijanja, a da je protivnik pobijanja na to, u najmanju ruku, pristao. To osobito vrijedi ako protivnik pobijanja ima odlučujući utjecaj na stečajnog dužnika kao većinski član društva ili najutjecajniji član njegovih organa jer tada može razmjerno lako iskoristiti svoj položaj i iz društva izvući najvrjedniju imovinu.

U praksi se ipak kao indicij dužnikove namjere oštećenja vjerovnika najčešće uzima dužnikova (prijeteća) nesposobnost za plaćanje. To je, uostalom, kodificirano dvjema zakonskim presumpcijama na temelju kojih se iz okolnosti da je protivnik pobijanja znao ili morao znati da dužniku prijeti nesposobnost za plaćanje izvodi zaključak da je ujedno i znao za dužnikovu namjeru oštećenja vjerovnika. Stječe se dojam da se sudska praksa na te presumpcije katkad i slijepo oslanja. Ne bi se, naime, trebalo složiti s odlukama u kojima su sudovi odbili dalje raspravljati o dužnikovoj namjeri i znanju treće osobe jer u vrijeme 
poduzimanja radnje dužniku nije prijetila nesposobnost za plaćanje ne vodeći pritom računa o tome da je stečajni dužnik mogao oštetiti svoje vjerovnike i znatno prije nego što mu je zaprijetila insolventnost.

Ne bi se, međutim, trebalo složiti ni s drugom krajnošću pa iz okolnosti da je dužnik bio nesposoban za plaćanje umah zaključivati o njegovoj namjeri oštećenja vjerovnika i znanju protivnika pobijanja. Ne smije se, naime, izgubiti iz vida da i osobe koje su nesposobne za plaćanje mogu imati opravdane razloge za poduzimanje pravnih radnji. Dapače, bez toga ne bi bilo ni zamislivo da se ikada izvuku iz krize pa bi prvi znaci financijskih problema dovodili do potpune obustave poslovanja. Treba se stoga složiti sa sudskom praksom koja radnje insolventna dužnika promatra kroz prizmu dužnikove namjere sanacije društva. Ako je stečajni dužnik dokazao da je imao razloga smatrati da se poduzetom radnjom može izvući iz krize, čak i ako to nije bilo osobito vjerojatno, ne može se govoriti o namjeri oštećenja vjerovnika.

Pri utvrđivanju znanja protivnika pobijanja za dužnikovu namjeru treba voditi računa i o tome da protivnik pobijanja nije nužno morao biti upoznat $s$ dužnikovom (prijetećom) nesposobnošću za plaćanje. Indiciji znanja protivnika pobijanja mogu biti bliska povezanost dužnika i protivnika pobijanja, njihova dugogodišnja poslovna suradnja, medijski napisi, neuobičajeni načini ispunjenja obveze te standard profesionalne dužne pažnje koji od protivnika pobijanja, osobito ako je banka, traži da provjerava bonitet stečajnog dužnika.

Uopće se može reći da ni za dokazivanje dužnikove namjere oštećenja vjerovnika ni znanja protivnika pobijanja za tu namjeru ne postoji univerzalna formula. Sud slobodno ocjenjuje okolnosti svakoga pojedinog slučaja. Što je više utvrđenih indicija, veća je vjerojatnost uspješna pobijanja suspektne pravne radnje. Ne treba pritom zaboraviti da ni namjeru ni znanje nije lako dokazati te se ne bi smjelo olako zaključivati da su sve radnje kongruentna ili inkongruentna pokrića ili pak izravna oštećenja vjerovnika, a koje nisu poduzete u neposrednoj blizini prijedloga za otvaranje (pred)stečajnog postupka (da bi bile pobojne po tim posebnim zakonskim osnovama), radnje namjernog oštećenja vjerovnika. Usprkos tomu što iura novit curia, ovlašteni bi pobijatelj morao imati jasnu viziju po kojoj osnovi pobija pojedinu suspektnu radnju te sudu iznijeti one činjenice koje su za tu osnovu relevantne.

Valja ovdje reći i da su odredbe o pobijanju pravnih radnji stečajnog dužnika u Stečajnom zakonu, baš kao i odgovarajuće odredbe njemačkog prava koje su im poslužile kao uzor, suviše složene i gdjegdje teško razumljive te su dijelom i uzrok pojedinim lutanjima u praksi i nepredvidivosti ishoda pobijajućih parnica. Kritička ocjena sudske prakse, kakva u našoj stručnoj literaturi nerijetko izostaje, može stoga pripomoći pravilnu razumijevanju pojedinih osnova pobijanja te 
pro futuro biti vrlo korisna u uspostavljanju pravične ravnoteže između interesa stečajnih vjerovnika, dužnika i protivnika pobijanja u pobijajućim parnicama.

\section{BIBLIOGRAFIJA}

Bilić, A., Pretpostavke pobijanja dužnikovih pravnih radnji po Zakonu o obveznim odnosima i Stečajnom zakonu, Aktualnosti zakonodavstva i prakse, vol. 24, 2017. str. 281-344

Bork, R., Einführung in das Insolvenzrecht, Mohr Siebeck, ${ }^{6} 2012$.

Čuveljak, J., Komentar Stečajnog zakona (NN 71/15, 104/17), Narodne novine, 2018.

Dika, M., Pobijanje pravnih radnji u povodu stečaja, u: Dika, M. (ur.), Treća novela Stečajnog zakona, Narodne novine, 2003., str. 141-209

Dika, M., Pravne posljedice otvaranja stečajnoga postupka, Narodne novine, 2002.

Eraković, A., Pobijanje dužnikovih pravnih radnji, Pravo i porezi, vol. 19, br. 1, 2010., str. 12-22

Garašić, J., Najznačajnije novine Stečajnog zakona iz 2015. godine, Zbornik Pravnog fakulteta Sveučilišta u Rijeci, vol. 38, br. 2, 2017., str. 131-186

Henckel, W., Anfechtung im Insolvenzrecht. Kommentar, De Gruyter Recht, 2008.

Hirte, H; Vallender, H. (ur.), Insolvenzordnung, Franz Vahlen, ${ }^{15} 2019$.

Hrastinski Jurčec, Lj., Novine u zakonskom uređenju instituta pobijanja pravnih radnji stečajnog dužnika, Informator, vol. 63, br. 6398, 2015., str. 6-8

Hrastinski Jurčec, Lj., Novine u zakonskom uređenju instituta pobijanja pravnih radnji stečajnog dužnika. 2. dio, Informator, vol. 64, br. 6399, 2016., str. 6-8

Huber, M., Anfechtungsgesetz (AnfG). Gesetz über die Anfechtung von Rechtshandlungen eines Schuldners außerhalb des Insolvenzverfahrens, C. H. Beck, ${ }^{11} 2016$.

Klarić, P.; Vedriš, M., Građansko pravo, Narodne novine, ${ }^{11} 2008$.

Kübler, B. M.; Prütting, H.; Bork, R. (ur.), InsO. Kommentar zur Insolvenzordnung, RWS, ${ }^{87} 2021$.

Kummer, J. et al., Insolvenzanfechtung. Fallgruppenkommentar, Otto Schmidt, ${ }^{3} 2017$.

Majstorović, D., Pobijanje pravnih radnji stečajnog dužnika u novom Stečajnom zakonu, Aktualnosti hrvatskog zakonodavstva i pravne prakse, vol. 22, 2015., str. 631-638

Maržić, D., Pobijanje pravnih radnji bez naknade (čl. 132. Stečajnog zakona) u odnosu na institute hipoteke i jamstva, Pravo i porezi, vol. 12, br. 1, 2003., str. 18-20

Pavlović, M., Pobijanje pravnih radnji u stečaju, Hrvatska pravna revija, vol. 3, br. 10, 2003., str. 90-108 
Radović, V., Stečajno pravo. Knjiga druga, Univerzitet u Beogradu, Pravni fakultet, ${ }^{2} 2018$.

Schmidt, K. (ur.), Insolvenzordnung. InsO mit EuInsVO, C. H. Beck, ${ }^{19} 2016$.

Skorup, V., Pobijanje pravnih radnji dužnika po Zakonu o obveznim odnosima i Stečajnom zakonu, Pravo u gospodarstvu, vol. 53, br. 2, 2014., str. 353-395

Stürner, R.; Eidenmüller, H.; Schoppmeyer, H. (ur.), Münchener Kommentar zur Insolvenzordnung, C. H. Beck, ${ }^{4} 2019$.

UNCITRAL Legislative Guide on Insolvency Law, United Nations, 2005.

\section{Sudska praksa}

VSRH, II Rev 3/1992-2 od 1. travnja 1992.

VSRH, II Rev 5/1996-2 od 8. svibnja 1996.

VSRH, II Rev 127/01-2 od 10. prosinca 2002.

VSRH, Rev 147/01-2 od 14. siječnja 2003.

VSRH, Gzz-296/2003-2 od 22. rujna 2004.

VSRH, Revt 90/05-2 od 5. listopada 2005.

VSRH, Revt 103/05-2 od 18. listopada 2005.

VSRH, Revt 19/05-2 od 29. studenog 2005.

VSRH, Revt 102/05-2 od 16. ožujka 2006.

VSRH, Revt 42/06-2 od 5. travnja 2006.

VSRH, Revt 34/07-2 od 28. ožujka 2007.

VSRH, Revt 44/06-2 od 28. ožujka 2007.

VSRH, Revt 146/06-2 od 16. svibnja 2007.

VSRH, Revt 125/06-2 od 13. lipnja 2007.

VSRH, Revt 72/07-2 od 4. srpnja 2007.

VSRH, Revt 65/07-2 od 3. listopada 2007.

VSRH, Revt 9/07-2 od 11. listopada 2007.

VSRH, Revt 157/07-2 od 19. ožujka 2008.

VSRH, Revt 66/07-2 od 21. svibnja 2008.

VSRH, Revt 155/07-2 od 28. listopada 2008.

VSRH, Revt 131/07-2 od 3. prosinca 2008.

VSRH, Revt 5/08-2 od 14. siječnja 2009.

VSRH, Revt 82/09-2 od 21. svibnja 2009. 
VSRH, Revt 94/09-2 od 16. rujna 2009.

VSRH, Revt 138/07-2 od 3. veljače 2010.

VSRH, Revt 97/10-2 od 23. ožujka 2011.

VSRH, Revt 208/12-2 od 4. srpnja 2012.

VSRH, Revt 45/12-2 od 12. veljače 2013.

VSRH, Revt 310/10-2 od 12. ožujka 2013.

VSRH, Revt 210/12-2 od 19. lipnja 2013.

VSRH, Revt 127/11-2 od 3. srpnja 2013.

VSRH, Revt 170/10-2 od 5. svibnja 2015.

VSRH, Revt 316/13-2 od 5. svibnja 2015.

VSRH, Revt 164/10-2 od 19. svibnja 2015.

VSRH, Revt 72/08-2 od 20. svibnja 2015.

VSRH, Revt 301/11-2 od 10. veljače 2016.

VSRH, Revt 195/16-2 od 13. rujna 2016.

VSRH, Revt 362/13-2 od 3. studenog 2016.

VSRH, Revt 134/12-2 od 16. studenog 2016.

VSRH, Revt 304/14-2 od 11. travnja 2017.

VSRH, Revt 78/16-2 od 30. svibnja 2017.

VSRH, Revt 78/14-2 od 11. listopada 2017.

VSRH, Revt 379/15-2 od 21. studenoga 2017.

VSRH, Revt 458/2017-3 od 26. veljače 2019.

VSRH, Revt 461/2016-3 od 15. svibnja 2019.

VSRH, Revt 364/2014-2 od 24. lipnja 2020.

VTS, Pž-2982/98 od 26. siječnja 1999.

VTS, P̌̌-2371/00-3 od 14. lipnja 2000.

VTS, Pž-5003/2001 od 19. ožujka 2002.

VTS, Pž-4677/01 od 19. ožujka 2002.

VTS, Pž-6013/02 od 13. listopada 2004.

VTS, P̌̌-425/03-4 od 27. travnja 2005.

VTS, Pž-197/04-5 od 10. svibnja 2005.

VTS, Pž-2182/02 od 14. lipnja 2005.

VTS, Pž-3901/02-3 od 28. lipnja 2005.

VTS, P̌̌-7427/04-3 od 12. srpnja 2005. 
VTS, P̌̌-8666/03-4 od 10. kolovoza 2005.

VTS, P̌̌-198/04 od 4. listopada 2005.

VTS, Pž-6797/04-3 od 4. listopada 2005.

VTS, Pž-3781/03-5 10. listopada 2005.

VTS, Pž-6630/03 od 8. studenog 2005.

VTS, P̌̌-8668/03-4 od 7. prosinca 2005.

VTS, P̌̌-1230/03 od 28. prosinca 2005.

VTS, Pž-7363/04-3 od 21. veljače 2006.

VTS, Pž-945/05-3 od 21. veljače 2006.

VTS, Pž-194/04-3 od 12. travnja 2006.

VTS, P̌̌-6671/03-4 od 25. travnja 2006.

VTS, P̌̌-0681/03-3 od 16. svibnja 2006.

VTS, Pž-3270/03-3 od 6. lipnja 2006.

VTS, Pž-1496/03-3 od 29. kolovoza 2006.

VTS, Pž-3778/03-5 od 6. rujna 2006.

VTS, Pž-7191/02-4 od 19. rujna 2006.

VTS, Pž-6430/03-3 od 27. rujna 2006.

VTS, Pž-203/04-3 od 24. listopada 2006.

VTS, Pž-3780/03-3 od 24. listopada 2006.

VTS, Pž-6380/03-4 od 24. listopada 2006.

VTS, Pž-6913/03-4 od 24. listopada 2006.

VTS, Pž-201/03-3 od 7. studenog 2006.

VTS, Pž-6902/03-5 od 15. studenog 2006.

VTS, Pž-3260/04-6 od 8. prosinca 2006.

VTS, Pž-7739/03-3 od 13. prosinca 2006.

VTS, Pž-3890/04-3 od 6. veljače 2007.

VTS, Pž-2502/05-3 od 27. veljače 2008.

VTS, Pž-572/04-3 od 7. ožujka 2007.

VTS, P̌̌-7312/04-3 od 2. listopada 2007.

VTS, Pž-4091/05-3 od 30. listopada 2007.

VTS, P̌̌-204/04-6 od 28. prosinca 2007.

VTS, Pž-2954/05-3 od 19. kolovoza 2008.

VTS, P̌̌-743/05-3 od 25. studenog 2008. 
VTS, P̌̌-3069/06-3 od 26. kolovoza 2009.

VTS, Pž-4810/06-3 od 16. rujna 2008.

VTS, P̌̌-6159/05-3 od 21. listopada 2008.

VTS, Pž-4204/06-3 od 18. studenog 2008.

VTS, P̌̌-3192/06-3 od 23. prosinca 2008.

VTS, P̌̌-4611/06-6 od 14. travnja 2009.

VTS, Pž-5868/06-3 od 6. listopada 2009.

VTS, pravno shvaćanje od 21. prosinca 2009. cit. u odluci USRH U-III-4963/2008 od 30. ožujka 2011.

VTS, P̌̌-1136/09 od 14. travnja 2010.

VTS, Pž-411/06-6 18. svibnja 2010.

VTS, Pž-4076/10-3 od 10. srpnja 2013.

VTS, P̌̌-8680/12-3 od 18. srpnja 2014.

VTS, Pž-9992/14-3 od 18. lipnja 2015.

VTS, P̌̌-4863/2013-3 od 15. ožujka 2017.

VTS, Pž-2810/2015-2 od 26. travnja 2017.

VTS, Pž-555/2016-2 od 31. svibnja 2017.

VTS, Pž-7184/2016-6 od 28. lipnja 2017.

VTS, Pž-8315/2015-3 od 28. ožujka 2018. 
Summary

Antun Bilić*

Marko Bratković**

\section{CONTESTABILITY OF INTENTIONAL DISADVANTAGING THE CREDITORS OF AN INSOLVENT DEBTOR}

It is clear from the case law of Croatian courts that intentional disadvantaging the creditors (regulated in Article 202 of the Insolvency Act) is the most commonly used ground for contesting the legal transactions of an insolvent debtor. On this ground, all legal transactions undertaken in the suspect period of as long as ten years before the submission of the application for opening (pre-)insolvency proceedings until the opening insolvency proceedings can be contested. The authorized contester, however, in litigation has a tall order of proving not only that the debtor took action with the intent to disadvantage its creditors but also that the opponent of the contestation was aware of that intent. The debtor's intent to disadvantage its creditors and the awareness of the opponent of the contestation are both determined on the basis of objective indications that are at the heart of the analysis of this paper. Incongruent settlement, the unequal value of consideration, unusual contractual clauses, the proximity of the insolvency debtor and the opponent of the contestation, and the debtor's (threatening) inability to pay his debts are most often recognized in case law as indications of intentional disadvantaging the creditors of an insolvent debtor. In addition to certain objections to the normative regulation of the institute itself, especially regarding the drafting of presumptions that make it easier to prove the contester's awareness of the debtor's intention to disadvantage its creditors, the paper presents a critical assessment of case law that could facilitate its harmonization and serve as a guide to authorized contesters as to whether it is appropriate to engage in contestation or not.

Keywords: contesting the legal transactions of an insolvent debtor, intent to disadvantage the creditors, awareness of the intent to disadvantage the creditors, legal transactions immediately disadvantaging the insolvency creditors, (threatening) inability to meet payments

* Antun Bilić, Ph. D., Assistant Professor, Faculty of Law, University of Zagreb, Trg Republike Hrvatske 14, 10000 Zagreb; antun.bilic@pravo.hr;

ORCID ID: orcid.org/0000-0001-5144-0821

** Marko Bratković, Ph. D., Assistant Professor, Faculty of Law, University of Zagreb, Trg Republike Hrvatske 14, 10000 Zagreb; marko.bratkovic@pravo.hr;

ORCID ID: orcid.org/0000-0003-0893-6682 